\title{
Age-Related Differences in ERP Components Associated with Processing Homonyms Depending on the Context Type of Adnominal and Verb Phrases
}

\author{
Eun Ha Jo, Jee Eun Sung \\ Department of Communication Disorders, Ewha Womans University, Seoul, Korea
}

Correspondence: Jee Eun Sung, PhD Department of Communication Disorders, Ewha Womans University, 52 Ewhayeodae-gil, Seodamun-gu, Seoul 03760, Korea

Tel: $+82-2-3277-2208$

Fax: +82-2-3277-2122

E-mail: jeesung@ewha.ac.kr

Received: April 5, 2018

Revised: May 31, 2018

Accepted: June 11, 2018

This work was supported by the Ministry of Education of the Republic of Korea and the National Research Foundation of Korea (No. NRF2017R1A2B4006604).

\begin{abstract}
Objectives: The purpose of this study was to investigate age-related differences in EventRelated Potentials (ERP) components associated with processing of homonyms according to the context type of adnominal and verb phrases. Methods: A total of 42 participants (young 22, elderly 20) participated in the study. The stimuli were Korean sentences containing homonyms. Each sentence had adnominal and verb phrase context, and each context was biased toward dominant meaning or subdominant meaning. The target sentences were classified into four conditions depending on these contexts. Results: The elderly group showed significantly lower accuracy and slower reaction time than the younger group. ERP results revealed that the $\mathrm{N} 400$ and $\mathrm{P} 600$ components emerged in the dominant meaning of the adnominal phrase context for the younger group, whereas the sustained negativity component emerged in the subdominant meaning of the adnominal phrase context. In contrast, the elderly group demonstrated delayed negativity in both the dominant and subdominant meanings of the adnominal phrase context. Conclusion: N400 and P600 components in the younger group reflect difficulties in integrating lexical expectancy and monitoring process which trigger reanalysis when integration fails. Sustained negativity in the subdominant meaning of the adnominal phrase context from the young group seems to be associated with additional processing costs of inhibiting the dominant meaning of homonyms, which is more frequently activated than the subdominant meaning. The delayed negativity in the elderly group can likely be attributed to slowed cognitive-linguistic processing in interpreting the homonyms.
\end{abstract}

Keywords: Elderly, Homonyms, Event-related potential, N400, P600
현재 우리나라는 고령화 사회에 진입한 이래로 노인 인구가 빠르 게 증가하고 있다. 이에 따라 노년층의 건강 및 사회. 경제적 문제에 대한 관심이 높아지고 있다. 정상적인 노화 과정에서도 인지능력의 감퇴가 관찰되며(Light, 1991), 여러 인지기능 가운데 사회생활의 기본적인 수단인 의사소통과 관련된 언어능력의 변화에 대해 특히 관심을 가질 필요가 있다.

원활한 의사소통을 위해서는 정확성과 명료성이 수반되어야 한 다. 따라서 하나의 언어표현이 둘 이상의 해석을 가능하게 하는 언 어현상인 중의성(ambiguity) 처리 과정에 대해 살펴보는 것은 의사 소통 정확성을 저해하는 요인을 파악하는 데 중요한 요소라 할 수
있다. 중의성은 문장을 구성하는 성분들 사이의 통사적 관계에 의 해서 나타나는 구조적 중의성(structural ambiguity)과 문장 속에 사용된 어휘의 특성에 의해서 나타나는 중의성인 어휘적 중의성 (lexical ambiguity)으로 나눌 수 있다. 이 중 어휘적 중의성을 해소 하기 위한 처리 과정에 대한 이론적 모형들은 크게 네 가지로 나뉘 어져 설명되어 왔다. 첫째, 맥락 의존적(context-dependent access) 모형은 어휘적 중의성이 맥락 속에 나타나면 맥락에 적합한 의미만 이 활성화된다고 보았다(Glucksberg, Kreuz, \& Rho, 1986; Simpson, 1981). 둘째, 순서적 접속(ordered access) 모형은 어휘적 중의성 의 의미 처리가 맥락에 관계없이 각 의미의 상대적 출현빈도에 따 
라 고빈도의 의미일수록 먼저 활성화된다고 보았으며, 이는 맥락과 의 일관성이 나타날 때까지 반복된다(Forster \& Bednall, 1976). 셋 째, 다중접속(multiple access) 모형은 어휘적 중의성의 의미 처리 시 항상 모든 의미가 맥락이나 의미 빈도와는 무관하게 활성화되 며, 맥락과 일치하는 의미는 모든 의미가 초기의 활성화 과정을 거 친 후에 선택된다고 보았다(Lucas, 1987; Onifer \& Swinney, 1981; Swinney, 1979). 넷째, 재순서 접속(reordered access) 모형은 어휘 적 중의성 처리 시 우세한 주요 의미만이 우선적으로 활성화된다 고 보았다. 즉, 부가 의미는 맥락에 의해서 활성화되는 반면, 주요 의 미는 맥락에 관계없이 활성화되어 처리부담이 증가한다고 보았다 (Duffy, Morris, \& Rayner, 1988).

특히 한국어의 경우 어휘적 중의성을 유발하는 대표적인 요소 로 동음이의어(homonyms) 현상을 들 수 있다. 동음이의어란 철자 와 발음이 동일한 단어가 서로 관련 없는 두 개 이상의 의미를 갖고 있는 단어를 의미한다. 실제로 1999년 국립국연구원에서 발간한 표준국어대사전의 약 34 만 개의 표제어 중 동음이의어는 약 10 만 개로 약 $30 \%$ 에 달한다(Kang, 2005). 이는 한자어가 전체 어휘의 약 $66 \%$ 를 차지하고 있으며(National Institute of Korean Language, 2005), 상이한 한자를 동일하게 발음하기 때문이다. 한국어에서 이 와 같이 동음이의어가 많은 빈도를 차지하고 있지만, 큰 어려움 없 이 의사소통을 할 수 있는 이유는 한국어 의사소통 방식이 맥락에 대한 의존도가 높기 때문이다(Kim, 2009). 하지만, 이러한 맥락에 대한 파악능력이 저하되거나, 맥락에 근거한 단서를 활용할 수 없 다면 동음이의어라는 어휘적 중의성 요소는 의사소통에 영향을 줄 수 있을 것이다. 특히, 노년층의 경우, 문장처리에 대한 능력이 감 소하고 있는 집단으로서 중의성 처리가 문장처리 어려움을 유발하 는 요소가 되는지 살펴볼 필요가 있다. 하지만, 문장 수준에서 제시 된 맥락에 따른 동음이의어 처리 과정을 다룬 국내연구는 제한적 이며, 특히 한국 노년층을 대상으로 한 연구는 없는 실정이다. 또한 기존 행동실험의 반응시간 및 정반응률은 인지적 처리 과정의 결 과물이기 때문에 언어 표상과 처리 과정의 기저를 이루는 복잡한 기제를 이해하기 위해 실시간 처리 과정(real-time online processing)에 관한 연구가 필요하다.

사건관련전위(Event-Related Potentials, ERP)는 특정한 자극이 주어졌을 때 그것에 대한 반응으로 일정한 시간 동안 나타나는 뇌 의 전기적 활동을 의미한다(Eum \& Kim, 2004). 이것은 시간해상 도(temporal resolution)가 높아 인지 및 언어적 처리 과정이 실시간 으로 기록되므로, 청년층과 노년층 간 동음이의어 처리능력의 차 이를 실시간으로 살펴보는 데 유용한 연구 패러다임이 될 수 있다.

언어관련 ERP 성분(component)으로는 N400과 P600이 대표적
이다. N400 성분은 의미적 오류(semantic violation)에 대한 반응으 로 관찰되는 부적 방향의 정점이며(Luck, 2014), 기존 맥락에 통합 하기 어렵거나, 기존 맥락을 토대로 예측하기 어렵거나, 선행 어휘 에 의한 어휘적 활성화 정도가 낮은 어휘가 나타날 경우에도 N400 이 관찰된다(Kutas \& Hillyard, 1984). P600 성분은 통사적 오류 (syntactic violation)에 대한 반응으로 관찰되는 정적 방향의 정점 이며(Luck, 2014), 단순히 통사적 위반뿐만 아니라 통사적으로 복 잡한 문장 처리 및 문장 전체 표상의 재구조화 또는 재분석 등의 영 향을 받는 문장 전체 구조의 의미 통합을 반영하는 성분으로 해석 되기도 한다(Brouwer, Fitz, \& Hoeks, 2012; Friederici, Hahne, \& Saddy, 2002; Kaan, Harris, Gibson, \& Holcomb, 2000). 많은 동음 이의어 관련 $\mathrm{ERP}$ 연구에서 동음이의어 처리 과정에서 N400 성분 이 관찰되었다고 보고하고 있으며(Jeong, Yun, \& Hong, 2015; Klepousniotou, Pike, Steinhauer, \& Gracco, 2012; Kwon, Cho, \& Nam, 2013; Lee \& Federmeier, 2012; Na, 2014; Swaab, Brown, \& Hagoort, 2003), 반면, 동음이의어 처리에 대한 P600 성분에 대한 보고는 매 우 제한적인 편이다(Jeong et al., 2015).

영어권에서 노화에 따른 동음이의어 처리능력 변화를 살펴본 선 행연구(Lee \& Federmeier, 2012)를 찾아볼 수 있었다. 기존 연구는 맥락의 의미적 제약으로 인한 동음이의어의 중의성 해소 능력에서 청년층과 노년층 간 차이가 있는지를 ERP 실험을 통해 살펴보았 다. 그 결과, 중의적인 조건에서 노년층이 청년층에 비해 N400 성분 이 감소하였으며, 동음이의어의 부가의미에서는 주요의미에서에 비해 N400이 감소하였다고 보고하였다. 이는 노년층의 경우, 중의 성을 해소하는 정보가 제공되는 시점까지 동음이의어의 두 가지 이상의 의미를 모두 활성화시켜 유지하는 데 어려움이 있기 때문으 로 보았다. 이처럼 청년층에 비하여 상대적으로 인지능력이 저하된 노년층을 대상으로 한 ERP실험에서 청년층과는 달리 진폭이 감소 하거나 지연되는 결과를 기대할 수 있을 것이다. 한국어 동음이의 어 처리에 대한 ERP 연구는 청년층에 국한되어 있으며, 노년층을 대상으로 한 연구는 찾아보기 어렵다. 정상 청년층을 대상으로 한 국내의 동음이의어 처리 관련 ERP 연구 중 어휘판단과제를 통해 동음이의어 처리 과정을 살펴 본 연구는 다음과 같다. Kwon 등 (2013)에서는 동음이의어 단어의 처리 과정과 비동음이의어 단어 의 처리 과정을 비교하였으며, 그 결과 동음이의어 처리 시에 더 큰 $\mathrm{N} 400$ 성분이 관찰되었다고 보고하였다. $\mathrm{Na}$ (2014)에서는 단어 빈 도를 고빈도와 저빈도로 분류하여, 동음이의어와 비동음이의어 간 의 빈도에 따른 효과를 비교하였다. 그 결과, 비동음이의어 조건에 비해 동음이의어 조건에서 $\mathrm{N} 400$ 이 강하게 발생하였으며, 고빈도 조건에 비해 저빈도 조건에서 더욱 강한 $\mathrm{N} 400$ 이 발생하는 것을 확 
인하였다. 앞의 두 연구와 달리, Jeong 등(2015)은 맥락유형에 따른 동음이의어의 처리 과정을 살펴보기 위해 동음이의어 전후에 편향 맥락이 포함된 문장을 사용한 문장판단과제를 실시하였다. 실험 시 문장 내의 동음이의어가 선행 맥락에 따라 주요의미, 부가의미 또는 중립의미로 활성화되도록 조작하였으며, 선행 맥락에 의해 활 성화되는 동음이의어의 의미가 주요의미에 해당할 때, 해당 맥락 이 갖는 어휘적 예측력이 클 것이라고 가정하였다. 그 결과, 주요의 미 맥락 조건에서 활성화된 동음이의어의 의미가 전체 문장의 의 미와 부합하지 않는 경우 어휘적 예측의 실패에 따른 N400과 전체 의미 통합의 어려움을 반영하는 P600이 함께 관찰되었다. 반면, 부 가의미 맥락 조건에서 활성화된 동음이의어의 의미가 전체 문장의 의미와 부합하지 않는 경우에는 P600만 나타났다. 이는 동음이의 어에서 주요의미 맥락 조건과 부가의미 맥락 조건에 따른 효과가 $\mathrm{N} 400$ 으로 반영된 선행연구와도 일맥상통하는 결과이다(Klepousniotou et al., 2012; Swaab et al., 2003).

이와 같이 국내에서 정상 청년층을 대상으로 동음이의어 처리 과 정을 살펴본 $\mathrm{ERP}$ 연구는 있었으나 노화에 따른 한국어 동음이의 어 처리에 따른 차이를 살펴본 ERP 연구는 없었다. 또한 언어병리 학에서 $\mathrm{ERP}$ 를 적용하여 동음이의어 처리 과정을 연구하고자 하는 것은 궁극적으로 동음이의어 처리 과정을 밝혀 중의성 해소에 문제 가 나타나는 단계 혹은 수행력 저하를 보이는 의미 표상 등을 밝혀 원활한 의사소통을 가능하도록 적절하고, 효율적인 중재를 제공하 기 위한 것이다. 즉, 문장 수준에서 청년층과 노년층을 비교하여 노 화에 따른 동음이의어 처리 시 $\mathrm{ERP}$ 성분들의 출현 특징을 정리할 필요가 있다. 이에 본 연구에서는 한국어를 모국어로 하는 청년층 과 노년층을 대상으로 문장판단과제를 실시하여 한국어 동음이의 어 처리 시 N400 성분과 P600 성분의 차이를 살펴보고자 하였다.

본 연구에서는 Jeong 등(2015)의 기존 연구 패러다임을 노년층에 적용하여 동음이의어 전후에 편향 맥락이 포함된 구문을 제시한 후, 각 문장이 의미적으로 적합한지를 판단하는 문장판단과제를 실시하였다. 각 문장은 하나의 동음이의어와 이에 선행하는 관형 어 맥락과 동사구 맥락을 포함하며, 각각의 맥락은 동음이의어의 주요의미에 편향된 경우 ‘주요의미 맥락', 부가의미에 편향된 경우 '부가의미 맥락'으로 나뉜다. 관형어 맥락은 동음이의어의 의미를 한정하고 이에 따라 뒤따라올 적절한 동사구 맥락유형을 결정하 며, 동사구 맥락은 관형어 맥락유형에 의해 한정된 동음이의어의 의미와 같은 의미로 편향되었는지에 따라 문장의 적합성을 결정하 는 역할을 한다. 관형어 맥락 유형과 동사구 맥락유형이 일치하는 경우에는 적합한 문장으로 판단되며, 일치하지 않는 경우에는 부 적합한 문장으로 판단하는 패러다임을 사용하였다.
또한 일반적으로 N400은 300-500 ms, P600은 500-700 ms 구간 에서 관찰된다고 알려져 있다(Kutas \& Hillyard, 1983). 그러나 노 년층을 대상으로 N400과 P600 성분을 측정한 선행연구(Federmeier \& Kutas, 2005; Lee \& Federmeier, 2012; Olichney et al., 2008; Taler, Klepousniotou, \& Phillips, 2009; Yoon, 2015)에서는 N400, $\mathrm{P} 600$ 성분이 일반적으로 관찰되는 구간을 포함하는 광범위한 시 간 창을 설정하고 있다. 따라서, 본 연구에서는 선행연구(Federmeier \& Kutas, 2005; Olichney et al., 2008)를 참고하여 N400 성분을 분석하기 위한 시간 창을 $300-500 \mathrm{~ms}, \mathrm{P} 600$ 성분을 분석하기 위한 시간 창을 500-800 ms로 설정하였다.

본 연구의 목적은 한국어를 모국어로 하는 정상 청년층과 노년 층을 대상으로 $\mathrm{ERP}$ 실험을 진행하여 동음이의어 처리 시 맥락 유 형에 따라 자극 제시 후 300-500 ms, 500-800 ms 구간의 평균진폭 (mean amplitude)의 차이가 있는지 알아보고자 하는 것이다.

본 연구의 구체적인 질문은 다음과 같다.

첫째, 관형어 및 동사구 맥락 유형에 따라 문장판단과제의 정반 응률에서 청년층 및 노년층 집단 간차이가 유의한가?

둘째, 관형어 및 동사구 맥락 유형에 따라 문장판단과제의 반응 시간에서 집단 간 차이가 유의한가?

셋째, 관형어 및 동사구 맥락 유형에 따라 자극제시 후 300-500 $\mathrm{ms}$ 구간의 평균진폭 크기에서 집단 간 차이가 유의한가?

넷째, 관형어 및 동사구 맥락 유형에 따라 자극제시 후 500-800 $\mathrm{ms}$ 구간의 평균진폭 크기에서 집단 간차이가 유의한가?

\section{연구방법}

\section{연구대상}

청년층 22 명과 노년층 20 명, 총 42 명이 본 연구에 참여하였다. 청년 층은 만 20-40세, 노년층은 만 60-80세로 집단을 구분하였다(Table 1).

모든 대상자는 공통적으로 (1) 한국어를 모국어로 사용하며, (2) 교육연수가 6년 이상이며, (3) 서울, 경기지역에 거주하며, (4) 오른 손잡이이고 시력 혹은 교정시력이 정상이며, (5) 언어 및 인지발달

Table 1. Demographic information on participants

\begin{tabular}{lcc}
\hline & Young group ( $\mathrm{N}=22)$ & Elderly group (N=20) \\
\hline Gender & & \\
Male & 8 & 6 \\
Female & 14 & 14 \\
Age (yr) & $27.59(5.03)$ & $65.60(2.46)$ \\
Education (yr) & $15.63(1.47)$ & $11.85(2.50)$ \\
\hline
\end{tabular}

Values are presented as number or mean (SD). 
에 문제가 없고 신경학적, 정신적 병력이 없는 자이며, (6) 한국판 간 이정신상태검사(Korean version of Mini-Mental State Exam, KMMSE; Kang, 2006)결과가 연령 및 교육수준에 따라 정상 범위 (16\%ile) 이상에 속하는 경우 대상자로 선정하였다.

노년층은 추가적으로 서울신경심리검사(Seoul Neuropsychological Screening Battery, SNSB; Kang \& Na, 2003)의 하위항목 중, 언어처리과제와 관련이 있는 구어기억검사에 해당하는 서울언어 학습검사(Seoul Verbal Learning Test, SVLT; Kang \& Na, 2003)와 집행기능 평가 범주에 해당하는 숫자 따라말하기 검사(Digit Span Test; Kang \& Na, 2003)를 실시하여, 각 하위 과제의 점수가 연령 및 교육연수를 반영하여 $16 \%$ ile 이상인 자로 선정하였다.

\section{실험 자극}

본 연구에서 사용되는 문장은 Jeong 등(2015)과 동일한 구문구 조를 사용하였으며, 동음이의어가 목적어 자리에 오는 '주어+관형 어+목적어+부사어+서술어'의 5 어절 문장으로 구성하였다. 단, 문 장을 구성하는 동음이의어(목적어)와 관형어, 동사구(부사어, 서 술어)의 선정은 노년층 대상자를 고려하여 아래와 같은 기준으로 변형하였다.

실험 자극에는 총 20 개의 동음이의어가 사용되었으며, 다음의 기준을 통해 선정되었다. 실험에 사용된 모든 동음이의어는 (1) 2음 절 단어 중에서 선정되었으며, (2) 21세기 세종 말뭉치(National Institute of Korean Language, 2000)를 사용하여 빈도 1,000 이상의 고빈도 어휘 중에서 선정되었다. 빈도에 따라 하나의 동음이의어에 대해 높은 빈도로 사용되는 의미를 주요의미, 낮은 빈도로 사용되 는 의미를 부가의미로 구분하였으며, 주요의미와 부가의미 간의 차 이를 명확하게 하기 위해, (3) 주요의미와 부가의미 간 빈도의 차이 가 500 이상 나도록 하였다. 또한, 부가의미의 사용빈도가 너무 낮 아 일반적으로 사용되지 않는 경우를 방지하기 위해, (4) 부가의미 의 빈도가 적어도 50 이상이 되도록 선정하였다.

하나의 동음이의어에 대해 관형어 맥락유형과 동사구(부사어+ 서술어) 맥락유형에 따라 총 4 가지 문장이 구성되었다. 각 맥락유형 의 의미의 편향성에 따라, 관형어 맥락유형과 동사구 맥락유형은
각각 ‘주요의미 맥락’과 ‘부가의미 맥락'으로 나누어졌다. 예를 들 면, “여자가 다친 다리를 몹시 절다”라는 문장에서 목적어 “다리(신 체부위-legs)'에 선행하는 관형어 맥락인 '다친'과 후행하는 동사구 맥락인 '몹시 절다’는 모두 동음이의어인 '다리’의 주요의미에 편향 된 ‘주요의미 맥락'으로 일치하여 의미적으로 적합한 문장을 구성 한다. 반면, “여자가 다친 다리를 간신히 건너다”라는 문장에서는 관형어 맥락인 '다친'은 동음이의어 '다리(구조물-bridge)'의 주요 의미에 편향된 '주요의미 맥락'이지만 동사구 맥락인 '간신히 건너 다'는 부가의미에 편향된 '부가의미 맥락'으로 관형어 맥락유형과 동사구 맥락유형이 일치하지 않아 의미적으로 부적합한 문장이 된 다. 이에 따른 실험문장의 예시는 Table 2에 제시하였으며, 전체 실 험문장의 목록은 Appendix 1에 제시하였다.

$\mathrm{ERP}$ 실험 시 동음이의어 전후의 편향 맥락이 모두 제시된 문장 의 마지막 단어인 동사가 '실험 단어(critical word)'가 되며, 동사가 제시되기 $200 \mathrm{~ms}$ 전부터 제시되고 난 후 $900 \mathrm{~ms}$ 까지를 $\mathrm{ERP}$ 분석 범위로 설정하였다. 각 동음이의어에 대해 조건별로 20 개의 문장 이 만들어졌으며, 40 개의 메꿈 문장(filler sentence)을 하여 총 120 개 문항으로 구성하였다. 메꿈 문장은 동음이의어를 포함하지 않 은 실험문장과 동일한 구문구조의 5 어절 문장으로 제작되었으며, 메꿈문장도 실험문장과 마찬가지로 의미적으로 적합한 문장(예: 남자가작은 과녁을 정확히 맞추다)과 부적합한 문장(예: 여자가 넓 은 바다를 잘게 자르다)의 수를 동일하게 맞추었다.

\section{실험 절차}

실험 자극은 총 120 개 문항으로 유사무작위 배열(pseudo-randomization)하여 40문항씩 3세트로 구성되었으며, 한 세트가 끝난 후에는 약 1 분간 휴식하였다. ‘+' 표시가 화면 가운데 나타나 피험 자의 시선을 고정시키고 5어절 문장이 한 어절씩 나타났다 사라진 뒤, 주어를 생략한 4어절 문장을 다시 한 번 제시하였다. 피험자에 게는 전체 문장이 제시되었을 때 '문장이 자연스럽고 말이 된다'라 고 생각하면 키보드 오른쪽에 표시된 파란색 버튼을, '문장이 자연 스럽지 않고 말이 안 된다’라고 생각하면 왼쪽에 표시된 빨간색 버 튼을 누르도록 하였으며, 반응 시에는 가능한 빠르고 정확하게 버

Table 2. Examples of experimental sentences

\begin{tabular}{|c|c|c|c|c|c|c|c|}
\hline \multirow{2}{*}{ Congruency } & \multicolumn{2}{|c|}{ Context } & \multicolumn{5}{|c|}{ Sentence } \\
\hline & Adnominal & Verb & Subject & Adnominal & Object & Adverb & Verb \\
\hline Congruent & Dominant & Dominant & yeoca-ka & tachin & tali-lul & kansinhi & kenneta \\
\hline Incongruent & Dominant & Subdominant & & & & mopsi & ceolta \\
\hline Congruent & Subdominant & Subdominant & namca-ka & copun & & kansinhi & kenneta \\
\hline Incongruent & Subdominant & Dominant & & & & mopsi & ceolta \\
\hline
\end{tabular}




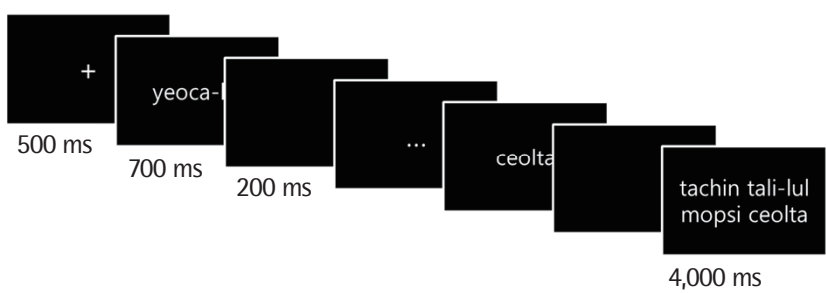

Figure 1. Experimental procedure.

튼을 누르도록 하였다.

시선을 고정하기 위해 ‘'’ 표시가 나타나는 시간은 $500 \mathrm{~ms}$ 이며, 한 어절씩 제시할 때의 1 어절 제시 시간은 $700 \mathrm{~ms}$ 로 하였다. 시선 고정 화면 및 어절 제시 화면 사이마다 $200 \mathrm{~ms}$ 의 빈 화면을 두었다. 어절 제시 후 나타나는 전체 문장은 최대 $4,000 \mathrm{~ms}$ 동안 제시되며, 피험자가 반응을 하면 바로 사라지도록 하였다. 문장판단과제의 자극 제시 순서는 Figure 1과 같다.

또한 피험자가 문장판단과제를 수행하는 동안에 뇌전도 녹화가 진행되었다. Brain Product사의 BrainAmp Standard와 actiCAP으 로 뇌전도를 측정하였으며, 뇌전도를 측정한 절차는 다음과 같다. 먼저 전파를 차단하도록 제작된 쉴드룸(shield room) 안에 피험자 의 두피에 전극을 부착하였다. 전극은 국제표준 방식인 10-20 system (Jasper, 1958)에 따라 Fp1, Fp2, F7, F3, Fz, F4, F8, FC5, FC1, FC2, FC6, T7, C3, C2, C4, T8, TP9, CP5, CP1, CP2, CP6, TP10, P7, $\mathrm{P} 3, \mathrm{Pz}, \mathrm{P} 4, \mathrm{P} 8, \mathrm{O} 1, \mathrm{O} 2$ 의 총 29개 부위에 부착하였다. 눈 깜박임을 탐지하기 위해 오른쪽 눈 밑 약 10-15 mm 위치에 전극을 부착하여 안전도(electrooculogram, EOG)를 측정하였다. 추가적인 기준 전 극(reference electrodes)은 피험자의 좌우 유양돌기(mastoids)에 부착하였다. 뇌파 신호는 $500 \mathrm{~Hz}$ 로 샘플링되었고, 전극저항은 $10 \mathrm{k} \Omega$ 이하로 유지하였다.

\section{자료분석}

정반응률

문장판단과제의 정반응률은 피험자가 '문장이 자연스럽고, 말 이 되는지' 혹은 '문장이 자연스럽지 않고, 말이 되지 않는지' 판단 한 반응을 분석하였다. 관형어 맥락유형 및 동사구 맥락유형 조건 별로 정반응한 목표문장 수를 전체 목표문장 수로 나누어 백분율 (\%)로 계산하였다.

\section{반응시간}

반응시간은 화면에 전체 문장이 제시된 순간부터 피험자가 '문 장이 자연스럽고, 말이 되는지' 혹은 '문장이 자연스럽지 않고, 말
이 되지 않는지' 판단하여 버튼을 누르기까지의 시간을 E-Prime을 통해 자동으로 측정하였다. 문장판단과제의 반응시간은 밀리세컨 드(ms) 단위로 측정하였다. 또한 피험자가 정반응한 문항에 대해서 만 분석하였으며, 각 피험자가 정반응한 모든 문항의 평균 반응시 간에 대해 피험자 내 표준편차(SD)를 구하여 $\pm 3 \mathrm{SD}$ 범위를 벗어 나는 값은 이상값(outlier)으로 처리하여 분석에서 제외하였으며, 이후 피험자 간 이상값을 같은 절차를 적용하여 분리하여 최종 분 석에서 제외하였다.

\section{ERP 분석}

피험자가 문장판단과제를 수행하는 동안 얻는 EEG 데이터를 MATLAB R2013b와 EEGLAB v12.02.2.5b 프로그램을 이용하여 분석하였다. 피험자들이 문장판단과제에서 정반응한 시행들만을 선택한 후, $250 \mathrm{~Hz}$ 로 다시 샘플링(sampling)한 뒤, 실험단어(문장 의 마지막 어절)가 제시되기 전 $200 \mathrm{~ms}$ 부터 실험단어가 제시되기 까지 $200 \mathrm{~ms}$ 구간을 기저선으로 하여 실험단어가 제시된 시점부터 실험 자극이 제시된 후 $900 \mathrm{~ms}$ 까지 총 1,100 ms 구간(epoch)을 잘 랐다. 인지작용과 관련된 뇌파 범위인 0.1-30 Hz로 대역 여과(bandpass filter)하였으며, 눈 깜박임을 보정하기 위해서 안구 교정(ocular correction)을 한 뒤 기타 잡음들(artifacts)을 없애기 위해 \pm 50 $\mu \mathrm{V}$ (micro volt)를 넘는 시행들(trial)은 제거하였다. 이러한 과정을 거친 후 남은 시행들을 관형어 맥락유형 및 동사구 맥락유형 조건 별로 추출하고 평균을 내어 각 집단의 평균 $\mathrm{ERP}$ 파형을 구하였다.

실험에 참여한 42 명(청년층 22 명, 노년층 20 명) 중 문장판단과제 의 정확도 및 반응시간에서 이상값(outlier)으로 제외된 노년층 1 명 을 제외한 총 41 명(청년층 22 명, 노년층 19 명)의 자료가 행동데이터 분석에 사용되었으며, ERP 데이터의 전처리 과정에서 제외된 노년 층 청년층 1 명을 제외한 총 40 명(청년층 21 명, 노년층 19 명)의 자료 가 ERP 데이터 분석에 사용되었다.

\section{통계적 처리}

두 집단(청년층, 노년층) 간 관형어와 동사구 맥락유형(주요, 부 가)에 따라 문장판단과제의 정반응률 및 반응시간의 차이가 유의 한지를 알아보기 위해 삼원혼합분산분석(three-way mixed ANO$\mathrm{VA})$ 을 실시하였다.

또한, 두 집단(청년층, 노년층) 간 관형어와 동사구 맥락유형(주요, 부가)에 따라 ERP의 평균진폭의 차이가 유의한지를 알아보기 위 해 중심선 영역에서는 사원혼합분산분석(four-way mixed ANO$\mathrm{VA})$, 좌우측 영역 및 전두-후두영역에서는 오원혼합분산분석(fiveway mixed ANOVA)을 실시하였다. 통계적 분석은 SPSS Statistics 
18 (SPSS Inc., Chicago, IL, USA)을 사용하였다.

\section{연구결과}

\section{관형어 및 동사구 맥락유형에 따른 집단 간 문장판단과제 행동 분석}

\section{정반응률}

관형어 및 동사구 맥락유형에 따른 동음이의어 문장에 대한 문 장판단과제의 정반응률은 Figure 2 와 같다. 문장판단과제의 정반 응률을 종속변수로 삼원혼합분산분석(three-way mixed ANOVA) 을 실시한 결과, 집단에 대한주효과가 통계적으로 유의하였다 $\left(F_{(1,39)}=\right.$ $70.628, p<.001)$. 즉, 청년층의 평균 정반응률 $(89.60 \%)$ 이 노년층의 평균 정반응률(68.42\%)보다 유의하게 높은 것으로 나타났다. 관형 어 맥락유형에 대한주효과도 통계적으로 유의하였다 $\left(F_{(1,39)}=109.781\right.$, $p<.001)$. 즉, 주요의미 관형어 맥락유형에서의 정반응률(85.48\%) 이 부가의미 관형어 맥락유형에서의 정반응률( $72.55 \%)$ 보다 유의하 게 높은 것으로 나타났다. 또한, 동사구 맥락유형에 대한 주효과도 통계적으로 유의하였다 $\left(F_{(1,39)}=31.061, p<.001\right)$. 즉, 주요의미 동사 구 맥락유형에서의 정반응률(81.70\%)이 부가의미 동사구 맥락유 형에서의 정반응률(76.32\%)보다 유의하게 높은 것으로 나타났다.

집단과 동사구 맥락유형 간의 이차 상호작용은 통계적으로 유의 하지 않았으나 $\left(F_{(1,39)}=.444, p>.05\right)$, 집단과 관형어 맥락유형 간의 이차 상호작용은 통계적으로 유의하였다 $\left(F_{(1,39)}=37.834, p<.001\right)$ 노년층에서의 명사수식언 맥락유형 간 정반응률의 차이가 청년층 에서의 관형어 맥락유형 간 정반응률의 차이보다 유의하게 큰 것으 로 나타났다. 즉, 정상 청년의 경우와 비교하여 정상 노년의 경우 주 요의미 관형어 맥락유형에 비해 부가의미 관형어 맥락에서 더 큰 수

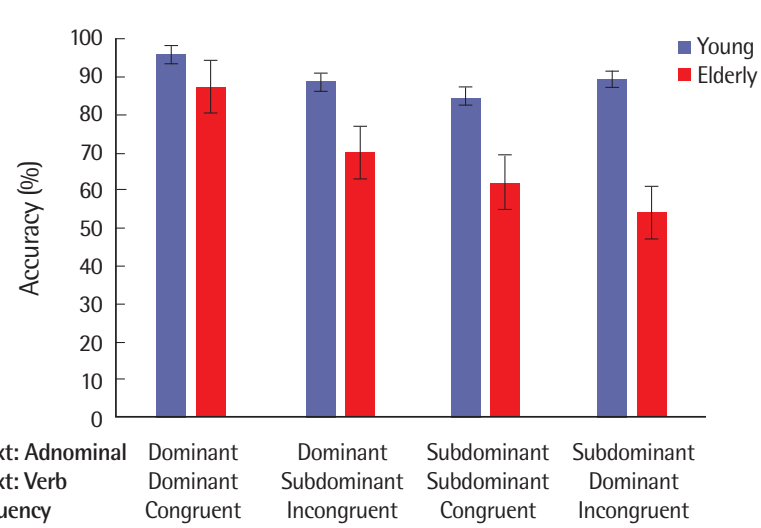

Figure 2. Accuracy of sentence judgment task for each condition in young and elderly groups. Error bars represent standard error.
행의 지체를 보였다. 또한, 관형어 맥락유형과 동사구 맥락유형 간의 이차상호작용도 통계적으로 유의한 것으로 나타났다 $\left(F_{(1,39)}=8.247\right.$, $p<.01)$. 주요의미 관형어 맥락유형에서 동사구 맥락유형 간 정반 응률의 차이가 부가의미 관형어 맥락유형에서 동사구 맥락유형 간 정반응률의 차이보다 유의하게 큰 것으로 나타났다. 즉, 부가의미 관형어 맥락유형과 비교하여 주요의미 관형어 맥락유형에서 주요 의미 동사구 맥락유형에 비해 부가의미 동사구 맥락유형에서 더 큰 수행의 지체를 보였다. 마지막으로, 집단, 관형어 및 동사구 맥락유 형 간 삼차상호작용도 통계적으로 유의하였다 $\left(F_{(1,39)}=6.544, p<.05\right)$. 노년층에서 관형어 맥락유형에 따른 동사구 맥락유형 간 정반응률 의 차이가 청년층에서 명사구 맥락유형에 따른 동사구 맥락유형 간 정반응률의 차이에 비해 유의하게 크게 나타났다. 즉, 정상 청년 의 경우와 비교하여 정상 노년의 경우 부가의미 관형어 맥락유형에 서의 동사구 맥락유형 간 정반응률의 차이가 주요의미 관형어 맥락 유형에서의 동사구 맥락유형 간 차이에 비해 더 큰 차이를 보였다.

반응시간

관형어 및 동사구 맥락유형에 따른 동음이의어 문장에 대한 문 장판단과제의 반응시간은 Figure 3 과 같다. 문장판단과제의 반응 시간을 종속변수로 삼원혼합분산분석(three-way mixed ANOVA) 을 실시한 결과, 집단에 대한주효과가 통계적으로 유의하였다 $\left(F_{(1,39)}=\right.$ $90.58, p<.001)$. 즉, 청년층의 반응시간 $(439.51 \mathrm{~ms})$ 이 노년층의 반 응시간 $(1,445.70 \mathrm{~ms})$ 에 비해 유의하게 더 빨랐다. 관형어 맥락유형 에 대한 주효과도 통계적으로 유의하였다 $\left(F_{(1,39)}=10.24, p<.005\right)$. 즉, 주요의미 관형어 맥락유형에서의 반응시간 $(907.12 \mathrm{~ms})$ 이 부가 의미 관형어 맥락유형에서의 반응시간 $(978.08 \mathrm{~ms})$ 에 비해 유의하 게 빨랐다. 또한, 동사구 맥락유형에 대한 주효과도 통계적으로 유

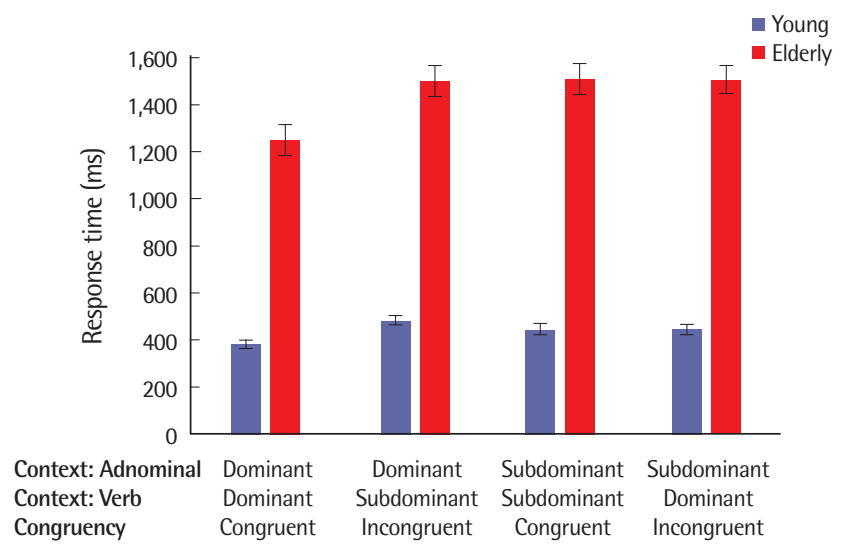

Figure 3. Response time of sentence judgment task for each condition in young and elderly groups. Error bars represent standard error. 
의하였다 $\left(F_{(1,39)}=15.56, p<.001\right)$. 즉, 주요의미 동사구 맥락유형에 서의 반응시간 $(897.26 \mathrm{~ms})$ 이 부가의미 동사구 맥락유형에서의 반 응시간 $(987.95 \mathrm{~ms})$ 에 비해 유의하게 빨랐다.

집단과 관형어 맥락유형 간의 이차상호작용이 통계적으로 유의 하였으나 $\left(F_{(1,39)}=7.30, p<.05\right)$, 그 외 상호작용은 유의하지 않았다. 노년층에서의 관형어 맥락유형 간 반응시간의 차이가 청년층에서 의 관형어 맥락유형 간 반응시간의 차이에 비해 유의하게 크게 나 타났다. 즉, 정상 청년의 경우와 비교하여 정상 노년의 경우 부가의
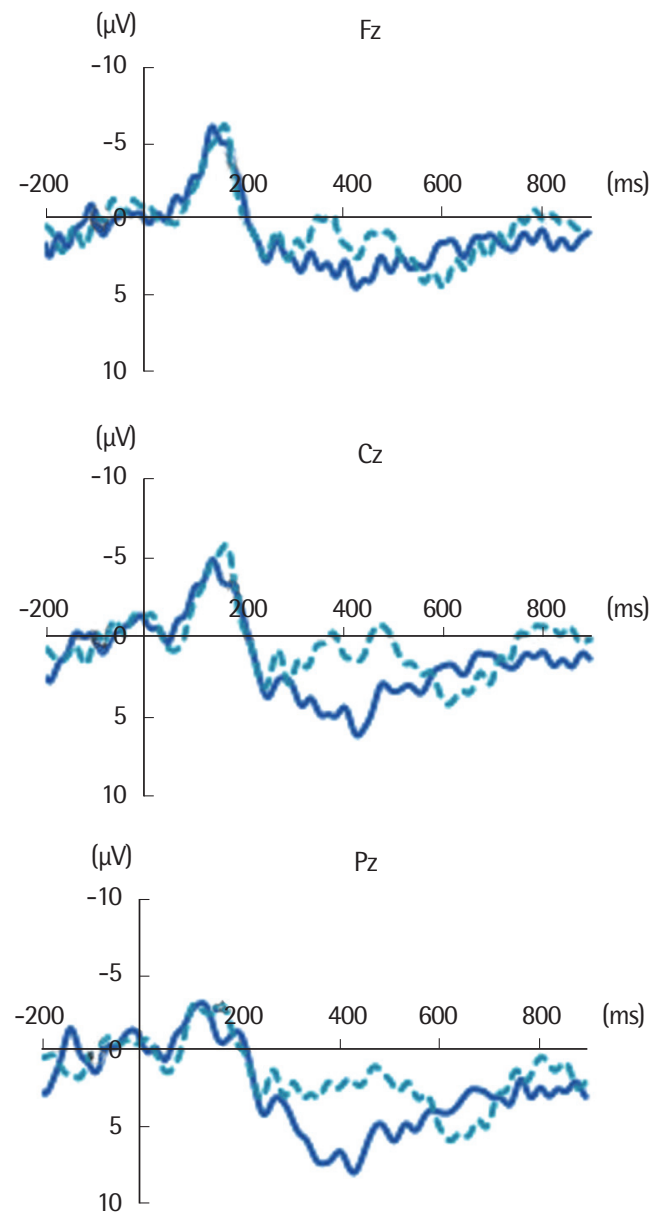

Verb phrase context: Dominant

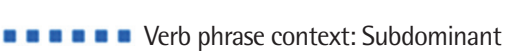

미 관형어 맥락유형에 비해 주요의미 관형어 맥락유형에서의 반응 시간이 더 빨랐다.

\section{관형어 및 동사구 맥락유형에 따른 집단 간 ERP 성분의}

\section{평균진폭 크기 분석}

청년층과 노년층의 ERP 분석에 따른 평균 파형(grand average waveforms) 결과는 Figures 4-7에 제시하였다.
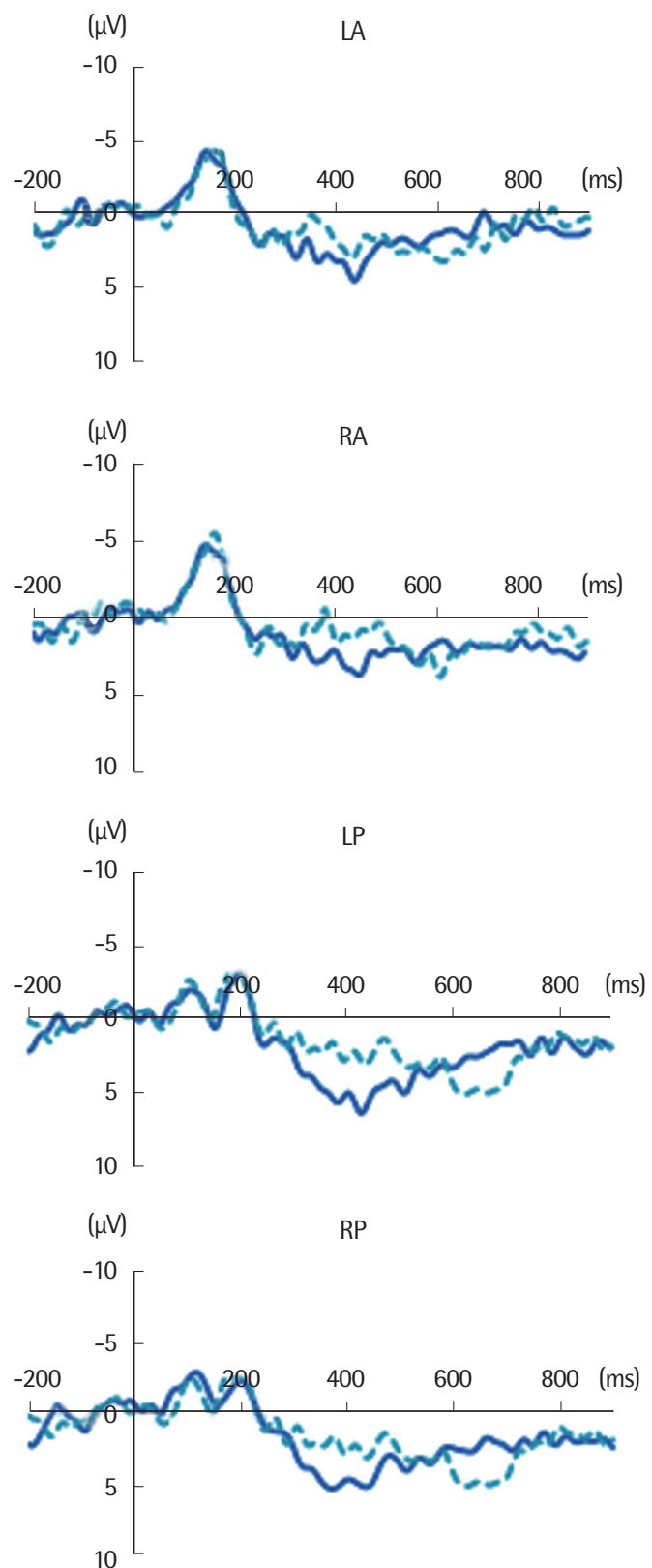

Figure 4. Grand average waves of the young group depending on the verb phrase context in the dominant adnominal phrase context. $\mathrm{LA}=$ left anterior; $\mathrm{RA}=$ right anterior; $\mathrm{LP}=$ left posterior; $\mathrm{RP}=$ right posterior. 

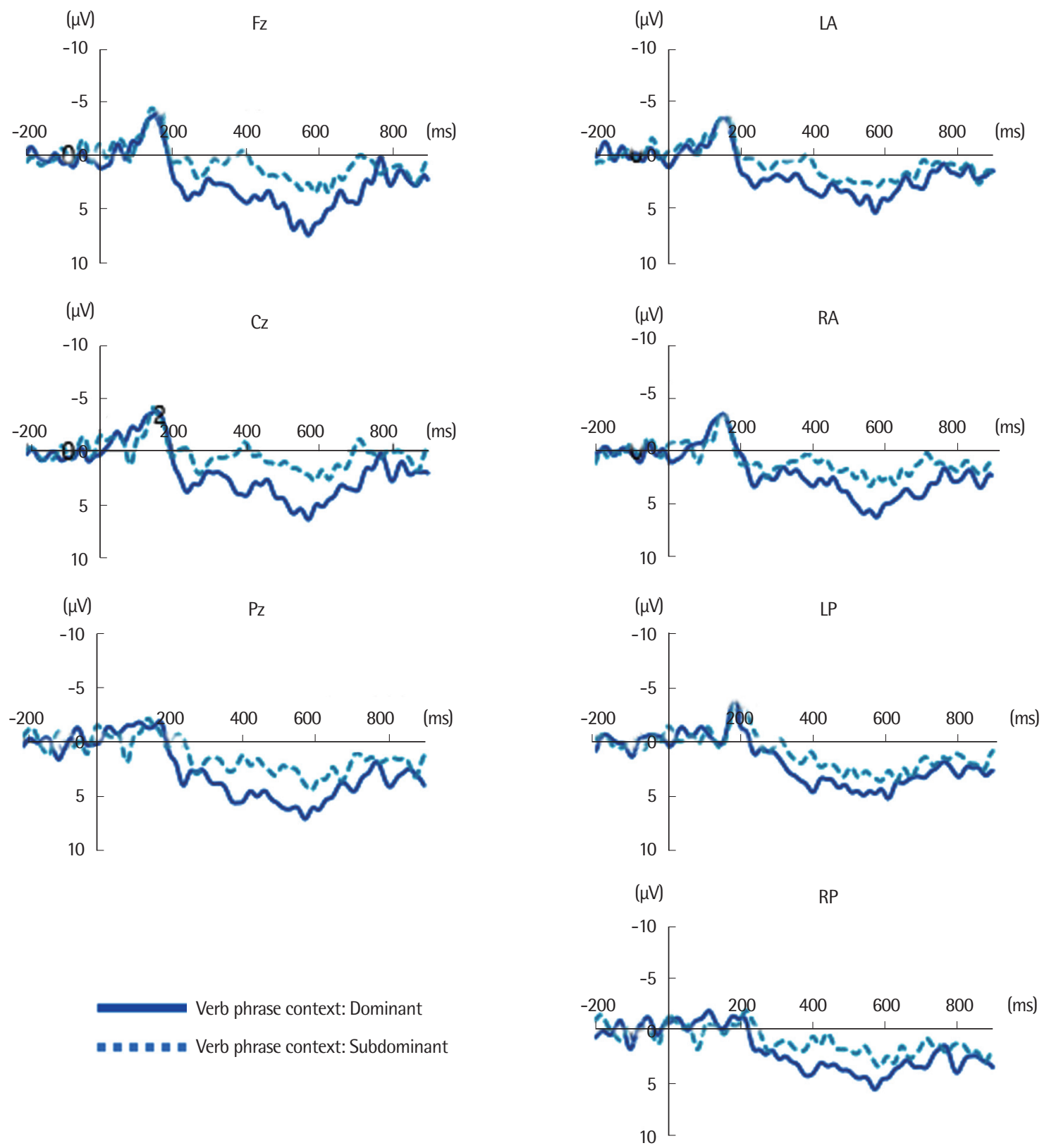

Figure 5. Grand average waves of the young group depending on the verb phrase context in the subdominant adnominal phrase context. $\mathrm{LA}=$ left anterior; $\mathrm{RA}=$ right anterior; $\mathrm{LP}=$ left posterior; $\mathrm{RP}=$ right posterior.

동사 제시 후 300-500 ms 구간

\section{중심선 영역 분석}

$300-500 \mathrm{~ms}$ 구간에서 중심선 영역의 집단 간 평균진폭 크기 차이 에 대한 사원혼합분산분석(four-way mixed ANOVA)을 실시한 결 과, 집단에 대한주효과가통계적으로 유의하였다 $\left(F_{(1,38)}=7.38, p<.05\right)$ 즉, $300-500 \mathrm{~ms}$ 구간에서 청년층의 평균진폭 $(2.69 \mu \mathrm{V})$ 이 노년층의 평균진폭 $(.06 \mu \mathrm{V})$ 에 비해 유의하게 더 큰 것으로 나타났다. 중심선 영역에 대한주효과도 통계적으로 유의하였다 $\left(F_{(1,76)}=29.82, p<.001\right)$
즉, 중심선 영역에 따라 동사 제시 후 300-500 ms 구간의 평균진폭 의 차이가 유의한 것으로 나타났다. 이에 따라 Bonferroni 사후검 정을 통하여 주효과에 대한 대응별 비교를 실시한 결과, 각 중심선 영역별 평균진폭 크기는 $\mathrm{Pz}(2.83 \mu \mathrm{V}), \mathrm{Cz}(1.13 \mu \mathrm{V}), \mathrm{Fz}(.17 \mu \mathrm{V})$ 순 으로 크게 나타났으며, $\mathrm{Fz}, \mathrm{Cz}, \mathrm{Pz}$ 간의 평균진폭 크기 차이가 모두 유의한 것으로 나타났다 $(p<.01)$. 반면, 명사수식언 맥락유형과 동 사구 맥락유형에 대한 주효과는 유의하지 않았다.

관형어 및 동사구 맥락유형 간 이차상호작용이 통계적으로 유의 

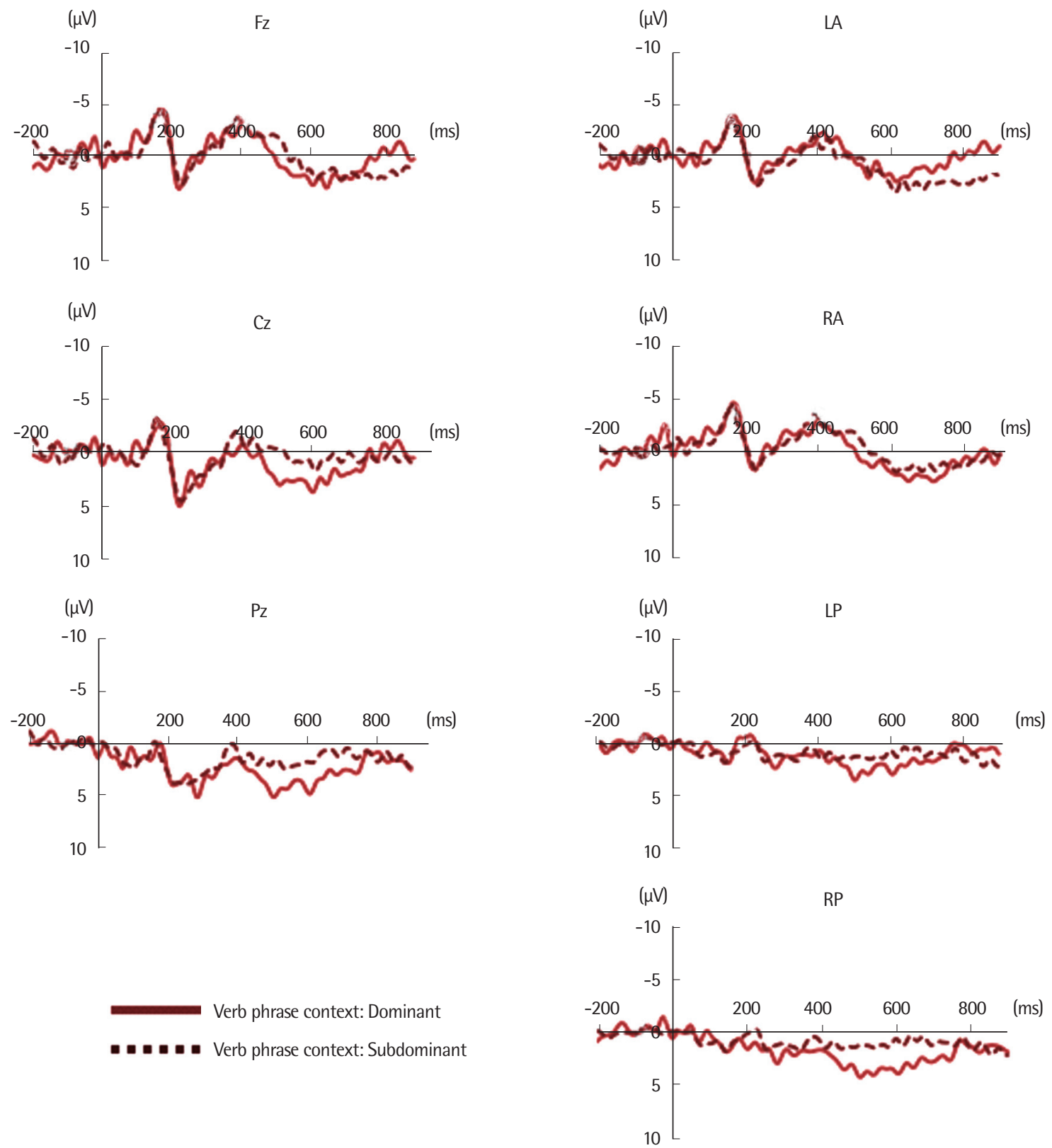

Figure 6. Grand average waves of the elderly group depending on the verb phrase context in the dominant adnominal phrase context.

$\mathrm{LA}=$ left anterior; $\mathrm{RA}=$ right anterior; $\mathrm{LP}=$ left posterior; $\mathrm{RP}=$ right posterior.

하였다 $\left(F_{(1,38)}=10.03, p<.01\right)$. 즉, 부가의미 명사수식언 맥락유형에 서 동사구 맥락유형 간 평균 차이가 주요의미 명사수식언 맥락유 형에서 동사구 맥락유형 간 평균진폭의 차이보다 유의하게 컸다. 중심선 영역과 집단 간 이차상호작용이 통계적으로 유의하였다 $\left(F_{(1,76)}=13.96, p<.05\right)$. 즉, 중심선 영역에 따른 집단 간 $300-500 \mathrm{~ms}$ 구간의 평균진폭 크기의 차이가 유의한 것으로 나타났다. LMATRIX와 MMATRIX 명령문을 사용하여 사후검정을 실시한 결과, $\mathrm{Fz}$ 에서의 집단 간 평균진폭의 차이가 $\mathrm{Cz}, \mathrm{Pz}$ 에서의 집단 간 평균진
폭의 차이보다 유의하게 큰 것으로 나타났다 $(p<.05)$. 중심선 영역 과 관형어 맥락유형 간 이차상호작용도 통계적으로 유의하였다 $\left(F_{(1,76)}=4.59, p<.05\right)$. 즉, 중심선 영역에 따른 관형어 맥락유형 간 $300-500 \mathrm{~ms}$ 구간의 평균진폭 크기의 차이가 유의한 것으로 나타났 다. LMATRIX와 MMATRIX 명령문을 사용하여 사후검정을 실 시한 결과, $\mathrm{Fz}, \mathrm{Cz}, \mathrm{Pz}$ 간 명사구 수식언 맥락유형에 따른 평균진폭 크기의 차이가 유의하지 않은 것으로 나타났다. 또한, 중심선 영역 및 관형어 맥락유형, 동사구 맥락유형 간 삼차상호작용이 통계적 

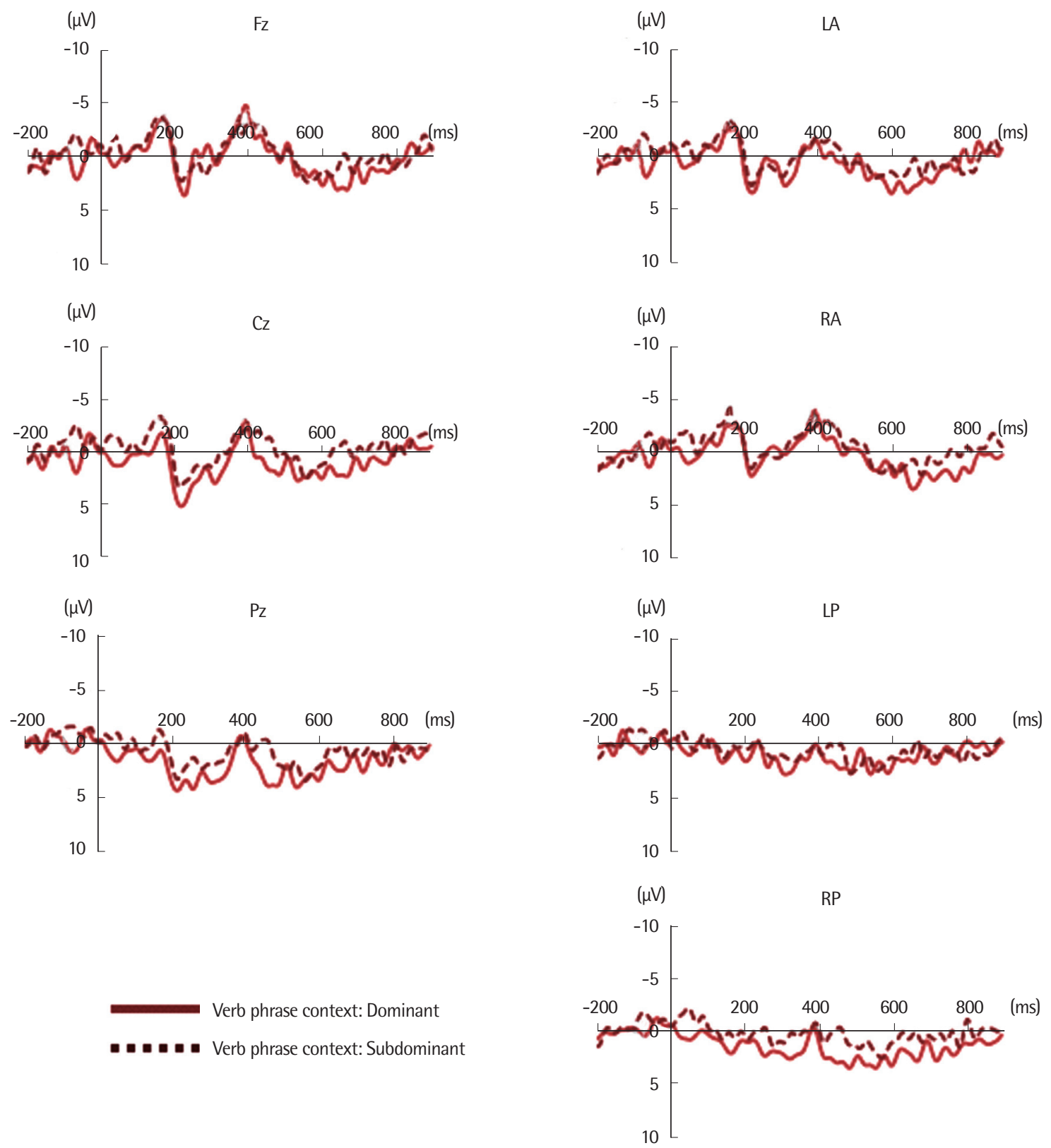

Figure 7. Grand average waves of the elderly group depending on the verb phrase context in the subdominant adnominal phrase context. $\mathrm{LA}=$ left anterior; $\mathrm{RA}=$ right anterior; $\mathrm{LP}=$ left posterior; $\mathrm{RP}=$ right posterior.

으로 유의하였다 $\left(F_{(1,76)}=4.35, p<.05\right)$. 즉, 중심선 영역 및 관형어 맥락유형에 따른 동사구 맥락유형 간 평균진폭 크기 차이가 유의 하였다. LMATRIX와 MMATRIX 명령문을 사용하여 사후검정을 실시한 결과, $\mathrm{Cz}$ 에서 관형어 맥락유형에 따른 동사구 맥락유형 간 평균진폭 크기 차이가 $\mathrm{Fz}$ 에서 관형어 맥락유형에 따른 동사구 맥 락유형 간 평균진폭 크기 차이보다 유의하게 큰 것으로 나타났다 ( $p<.05)$. 또한 삼차상호작용에 대한 사후검정으로 각 중심선 영역 에서 관형어 맥락유형에 따른 동사구 맥락유형 간 차이가 유의한
지 알아보기 위해 MMATRIX 명령문을 사용하여 사후검정을 실 시한 결과, $\mathrm{Fz}$ 에서 관형어 맥락유형에 따른 동사구 맥락유형 간 평 균진폭 크기의 차이는 유의하지 않은 반면, $\mathrm{Cz}$ 와 $\mathrm{PZ}$ 에서는 각각 관 형어 맥락유형에 따른 동사구 맥락유형 간 평균진폭 크기의 차이 가 유의하였다 $(p<.01)$.

\section{좌우측 영역 및 전두-후두 영역분석}

300-500 ms 구간에서 좌우측 영역 및 전두-후두 영역의 집단 간 
평균진폭 크기 차이 대한 오원혼합분산분석(five-way mixed ANO$\mathrm{VA}$ )을 실시한 결과, 집단에 대한 주효과가 통계적으로 유의하였다 $\left(F_{(1,38)}=11.55, p<.01\right)$. 즉, $300-500 \mathrm{~ms}$ 구간에서 청년층의 평균진 폭 $(2.38 \mu \mathrm{V})$ 이 노년층의 평균진폭 $(.23 \mu \mathrm{V})$ 에 비해 유의하게 큰 것으 로 나타났다. 좌우측 영역에 대한 주효과도 통계적으로 유의하였 다 $\left(F_{(1,38)}=5.42, p<.05\right)$. 즉, $300-500 \mathrm{~ms}$ 구간에서 좌측 영역의 평 균진폭 $(1.54 \mu \mathrm{V})$ 이 우측 영역의 평균진폭 $(1.07 \mu \mathrm{V})$ 에 비해 유의하 게 더 큰 것으로 나타났다. 또한, 전두-후두 영역에 대한 주효과도 통계적으로 유의한 것으로 나타났다 $\left(F_{(1,38)}=18.06, p<.001\right)$. 즉, $300-500 \mathrm{~ms}$ 구간에서 후두 영역의 평균진폭 크기 $(2.13 \mu \mathrm{V})$ 가 전두 영역의 평균진폭 크기(. $49 \mu \mathrm{V})$ 보다 유의하게 큰 것으로 나타났다.

관형어 및 동사구 맥락유형 간 이차상호작용이 통계적으로 유의 하였다 $\left(F_{(1,38)}=10.03, p<.005\right)$. 즉, 부가의미 관형어 맥락유형에서 동사구 맥락유형 간 평균진폭 크기의 차이가 주요의미 관형어 맥 락유형에서 동사구 맥락유형 간 평균진폭 크기의 차이보다 유의하 게 큰 것으로 나타났다. 관형어 맥락유형과 전두-후두 영역 간 이차 상호작용도 유의하였다 $\left(F_{(1,38)}=5.32, p<.05\right)$. 즉, 전두 영역에서의 관형어 맥락유형 간 평균진폭의 차이에 비해 후두 영역에서의 관형 어 맥락유형 간 평균진폭의 크기가 크게 나타났다. 좌우측 영역과 전두-후두 영역 간 이차상호작용도 통계적으로 유의하였다 $\left(F_{(1,38)}=\right.$ $8.69, p<.05)$. 즉, 좌측 영역에서의 전두-후두 영역 간 평균진폭의 차이에 비해 우측 영역에서의 전두-후두 영역 간 평균진폭의 크기 가 유의하게 큰 것으로 나타났다. 또한, 집단 및 좌우측 영역, 전두후두 영역 간 삼차상호작용이 통계적으로 유의하였다 $\left(F_{(1,38)}=10.32\right.$, $p<.01)$. 즉, 노년층에서 좌우측 영역에 따른 전두-후두 영역 간 평 균 진폭의 차이가 청년층에서 좌우측 영역에 따른 전두-후두 영역 간 평균진폭의 차이보다 유의하게 큰 것으로 나타났다. LMATRIX 와 MMATRIX 명령문을 사용하여 집단, 좌우측 영역, 전두-후두 영역 간 삼차상호작용에 대한 사후검정을 실시한 결과, 각 집단에 서 좌우측 영역에 따른 전두-후두 영역 간 차이가 유의하지 않았다 ( $p>$.05). 또한 관형어 맥락유형, 동사구 맥락유형, 좌우측 영역 간 삼차상호작용도 통계적으로 유의하였다 $\left(F_{(1,38)}=6.64, p<.05\right)$. 즉, 좌측 영역에서 관형어 맥락유형에 따른 동사구 맥락유형 간 평균 진폭의 차이가 우측 영역에서 관형어 맥락유형에 따른 동사구 맥 락유형 간 평균진폭의 차이에 비해 유의하게 컸다. 관형어 맥락유 형, 동사구 맥락유형, 좌우측 영역 간 삼차상호작용에 대해 MMATRIX를 사용하여 사후검정을 실시한 결과, 좌측 영역에서는 관형 어 맥락유형에 따른 동사구 맥락유형 간 차이가 유의하지 않은 반 면, 우측 영역에서는 관형어 맥락유형에 따른 동사구 맥락유형 간 차이가 유의하였다 $(p<.05)$. 마지막으로, 관형어 맥락유형, 동사구
맥락유형, 전두-후두 영역 간 삼차상호작용도 통계적으로 유의하 였다 $\left(F_{(1,38)}=4.16, p<.05\right)$. 즉, 전두 영역에서 관형어 맥락유형에 따 른 동사구 맥락유형 간 차이가 후두 영역에서 관형어 맥락유형에 따른 동사구 맥락유형 간 차이에 비해 유의하게 컸다. 관형어 맥락 유형, 동사구 맥락유형, 전두-후두 영역 간 삼차상호작용에 대해 MMATRIX를 사용하여 사후검정을 실시한 결과, 후두 영역에서 는 관형어 맥락유형에 따른 동사구 맥락유형 간 평균진폭 크기의 차이가 유의하지 않지만, 전두 영역에서는 관형어 맥락유형에 따른 동사구 맥락유형 간 평균진폭 크기의 차이가 유의하였다 $(p<.05)$.

\section{동사 제시 후 500-800 ms 구간}

중심선 영역 분석

500-800 ms 구간에서 중심선 영역의 집단 간 평균진폭 크기 차 이에 대한 사원혼합분산분석(four-way mixed ANOVA)을 실시한 결과, 500-800 ms 구간에서는 집단에 따른 평균진폭 크기의 차이 는 유의하지 않았으나, 중심선에 대한 주효과가 통계적으로 유의하 였다 $\left(F_{(1,78)}=4.26, p<.05\right)$. 이에 따라 Bonferroni 사후검정을 통하 여 주효과에 대한 대응별 비교를 실시한 결과, $\mathrm{Pz}$ 에서의 평균진폭 크기 $(2.79 \mu \mathrm{V})$ 가 $\mathrm{Cz}$ 에서의 평균진폭 크기 $(1.68 \mu \mathrm{V})$ 보다 유의하게 큰 것으로 나타났다 $(p<.05)$. 또한, 관형어 맥락유형과 동사구 맥락 유형 간 이차상호작용이 통계적으로 유의하였다 $\left(F_{(1,38)}=4.91, p<.05\right)$. 즉, 부가의미 관형어 맥락유형에서 동사구 맥락유형 간 평균진폭 크기 차이가 주요의미 관형어 맥락유형에서 동사구 맥락유형 간 평균진폭 크기 차이에 비해 유의하게 큰 것으로 나타났다. 그 외 주 효과 및 상호작용은 유의하지 않았다.

좌우측 영역 및 전두-후두 영역 분석

500-800 ms 구간에서 좌우측 영역 및 전두-후두 영역의 집단 간 평균진폭 크기 차이에 대한 오원혼합분산분석(five-way mixed ANOVA)을 실시한 결과, 유의한 주효과는 나타나지 않았으나, 명 사구 수식언 맥락유형 및 동사구 맥락유형 간 이차상호작용은 통 계적으로 유의하였다 $\left(F_{(1,38)}=4.24, p<.05\right)$. 즉, 중앙선 영역에서와 마찬가지로 부가의미 관형어 맥락유형에서 동사구 맥락유형 간 평 균진폭 크기의 차이가 주요의미 관형어 맥락유형에서 동사구 맥락 유형 간 평균진폭 크기의 차이보다 유의하게 컸다. 또한, 관형어 맥 락유형, 동사구 맥락유형, 좌우측 영역 간 삼차상호작용이 통계적 으로 유의하였다 $\left(F_{(1,38)}=13.19, p<.01\right)$. 즉, 좌측 영역에서 관형어 맥락유형에 따른 동사구 맥락유형 간 평균진폭 크기의 차이가 우 측 영역에서 관형어 맥락유형에 따른 동사구 맥락유형 간 평균진폭 크기의 차이에 비해 유의하게 컸다. 관형어 맥락유형, 동사구 맥락 
유형, 좌우측 영역 간 삼차상호작용에 대해 MMATRIX를 사용하 여 사후검정을 실시한 결과, 좌측 영역과 우측 영역 모두에서 관형 어 맥락유형에 따른 동사구 맥락유형 간 차이가 유의하지 않았다 ( $p>$.05). 집단, 좌우측 영역, 전두-후두 영역 간 삼차상호작용도 통 계적으로 유의하였다 $\left(F_{(1,38)}=10.29, p<.01\right)$. 즉, 청년층에서 좌우측 영역에 따른 전두-후두 영역 간 평균진폭 크기의 차이가 노년층에 서 좌우측 영역에 따른 전두-후두 영역 간 평균진폭 크기의 차이보 다 큰 것으로 나타났다. LAMATRIX와 MMATRIX 명령문을 사 용하여 집단, 좌우측 영역, 전두-후두 영역 간 삼차상호작용에 대 한 사후검정을 실시하였다. 그 결과, 청년층에서는 좌우측 영역에 따른 전두-후두 영역 간 차이가 유의한 반면 $(p<.05)$, 노년층에서는 좌우측 영역에 따른 전두-후두 영역 간차이가 유의하지 않았다.

\section{논의 및 결론}

본 연구의 목적은 관형어 맥락유형 및 동사구 맥락유형에 따라 동음이의어 의미 처리 시 청년층과 노년층 간 행동 데이터 및 ERP 성분의 평균진폭(mean amplitude) 크기에 차이가 있는지 알아보 고자 하는 것이었다. 이에 따라 청년층과 노년층을 대상으로 문장 판단과제를 실시하여 정반응률 및 반응시간을 측정하였으며, 동시 에 ERP 실험을 실시하여 과제 수행 시 관찰되는 ERP 성분의 평균 진폭을 측정하였다. 관형어 맥락유형 및 동사구 맥락유형에 따른 동음이의어 처리에 대한 집단 간 행동 데이터 및 ERP 성분의 평균 진폭 크기 차이는 다음과 같다.

먼저, 동사 제시 후 300-500 ms 구간에서 관형어 맥락유형에 따 른 동사구 맥락유형 간 평균진폭 차이가 유의하였다. 주요의미 관 형어 맥락유형에서 동사구 맥락유형 간 평균진폭의 부적 방향성이 부가의미 관형어 맥락유형에서 동사구 맥락유형 간 평균진폭의 부 적 방향성에 비해 더 크게 나타났기 때문인 것으로 나타났다. 즉, 동음이의어 처리 과정에서 선행 맥락에 따라 예측되는 동음이의어 의 의미가 전체 문장에서 의미적으로 적합하지 않아 어휘적 예측 의 실패로 인해 $\mathrm{N} 400$ 이 관찰되었다. 이는 어휘적 예측의 어려움으 로 관찰되는 N400을 보고한 선행연구의 결과와 일치한다(Jeong et al., 2015; Klepousniotou et al., 2012; Kwon et al., 2013; Na, 2014; Swaab et al., 2003). 또한 청년층의 경우 동음이의어 앞에 부가의미 맥락이 선행하는 경우 주요의미 맥락이 선행하는 경우보다 더 큰 $\mathrm{N} 400$ 이 관찰되었다. 이는 동음이의어와 다의어의 의미가 활성화 되는 방식을 비교하기 위해 점화실험을 실시한 Klepousniotou 등 (2012)의 결과와 일치한다. Klepousniotou 등(2012)은 동음이의어 처리와 관련하여 부가의미 조건에서보다 주요의미 조건에서 점화
효과가 더 강하게 발생하며, 이에 따라 주요의미 조건에서 감소한 $\mathrm{N} 400$ 이 관찰된다고 하였다. 본 연구에서는 동음이의어에 선행하 는 관형어 맥락이 동음이의어 의미 활성화에 영향을 미치는 점화 어의 역할을 수행하여 동음이의어 앞에 주요의미 맥락이 선행할 때 부가의미 맥락이 선행할 때보다 감소된 N400이 관찰되었다고 해석할수 있다.

한편, 노년층의 경우에도 동음이의어 처리 과정에서 어휘적 예측 이 문장 전체 의미에 부합하지 않는 경우 부적(negative) 성분이 관 찰되었으나, 300-500 ms 구간에서 부적 성분이 관찰된 정상 청년층 보다 지연된 500-800 ms 구간에서 부적 성분이 관찰되었다. 이는 정상 노년층의 뇌 수준으로부터의 동음이의어 처리능력의 약화 및 처리속도의 지연으로 인한 것으로 해석할 수 있다. 또한 노년층의 경우 부적 성분의 평균진폭이 정상 청년층에 비해 감소되는 것으 로 나타났다. 이는 노화에 따라 동음이의어 처리 시 부적성분의 평 균진폭이 감소한다는 선행연구 결과와 일치한다(Lee \& Federmei$\mathrm{er}, 2012)$. 특히, 정상 노년층은 동음이의어 앞에 부가의미 관형어 맥 락이 선행했을 때 중심선 및 우측 영역에서만 지연된 부적 성분을 보였으며, 전체적으로 정상 청년층에 비해 현저히 저하된 평균진폭 크기를 보였다. 정상 노년층의 경우 오프라인(off-line) 과제인 문장 판단 과제에서 부가의미 관형어 맥락유형 조건 평균 정반응률이 주 요의미 관형어 맥락유형 조건 평균 정반응률보다 유의하게 낮았으 며, 정상 노년층의 부가의미 관형어 맥락유형 조건의 평균 정반응 률은 약 $60 \%$ 로 우연 수준(chance-level)에 가까워 동음이의어 문장 에 대한 이해가 완전히 이루어지지 않은 영향으로 해석할 수 있다.

다음으로, 동사 제시 후 500-800 ms 구간에서도 관형어 맥락유 형에 따른 동사구 맥락유형 간 평균진폭 차이가 유의하였으며, 이 는 주요의미 관형어 맥락유형에서 주요의미 동사구 맥락유형 대비 부가의미 동사구 맥락유형의 평균진폭의 부적(negative) 방향성이 부가의미 관형어 맥락유형에서 부가의미 동사구 맥락유형 대비 주 요의미 동사구 맥락유형의 평균진폭의 부적 방향성에 비해 더 크 게 나타났기 때문인 것으로 나타났다. 동사 제시 후 500-800 ms 구 간에서 주요의미 관형어 맥락유형의 경우 정상 청년층은 주요의미 동사구 맥락유형 대비 부가의미 동사구 맥락유형의 평균진폭이 정 적(positive) 방향성을 띠는 반면, 정상 노년층은 평균진폭은 부적 방향성을 띤다. 또한 부가의미 관형어 맥락유형의 경우 정상 청년층 과 정상 노년층 모두 부가의미 동사구 맥락유형 대비 주요의미 동 사구 맥락유형의 평균진폭이 부적 방향성을 띤다.

먼저, 주요의미 관형어 맥락유형에서 동사구 맥락이 이와 일치하 지 않을 때 정상 청년층의 경우 300-500 ms 구간에서는 N400 성분 이 관찰되었으나, $500-800 \mathrm{~ms}$ 구간에서는 P600 성분이 관찰되었 
다. 이는 동음이의어 처리 시 선행 맥락으로 예측되는 동음이의어 의 의미와 전체 문장의 의미에 부합하지 않아 의미 통합의 실패로 $\mathrm{P} 600$ 이 관찰되었다. 즉, 의미 통합의 실패로 인해 문장의 재분석을 유발할 때 $\mathrm{P} 600$ 이 관찰되며, 의미 통합의 어려움으로 인해 관찰되 는 P600 성분을 보고한 선행연구의 결과와 일치한다(Dunn, Dunn, Languis, \& Andrews, 1998; Jeong et al., 2015; Pijnacker, Geurts, Van Lambalgen, Buitelaar, \& Hagoort, 2010; Smith, 1993) . 반면 주 요 관형어 맥락유형에서 정상 노년층의 경우 $500-800 \mathrm{~ms}$ 구간에서 좌측 전두(left anterior) 영역에서만 P600 성분이 관찰되었으며, 우 측 전두(right anterior) 영역을 제외한 나머지 영역에서는 지연된 부적 성분이 관찰되었다.

다음으로, 부가의미 관형어 맥락유형에서 정상 청년층과 정상 노 년층 모두 부적 성분이 관찰되었다. 그러나 정상 청년층의 경우 300 $500 \mathrm{~ms}$ 구간에서 500-800 ms 구간에 걸쳐 지속되는 부적 성분(sustained negativity)이 관찰된 반면, 정상 노년층의 경우 $500-800 \mathrm{~ms}$ 구간에서만 부적 성분이 관찰되었다. 이는 정상 청년층을 대상으 로 선행 맥락에 따른 동음이의어 처리를 살펴본 국내 선행연구에 서 부가의미 맥락이 선행하였을 때 $\mathrm{P} 600$ 이 관찰된 것과는 다른 결 과이다(Jeong et al., 2015). Jeong 등(2015)에서는 어휘적 예측이 강 할수록 해당 예측이 위반되었을 때 발생하는 N400이 크게 나타난 다고 보았으며, 어휘적 예측이 충족되지 못했을 때 기존 정보를 재 분석하고 전체 문장의 의미를 재통합하려는 노력이 P600에 반영 된다고 보았다. 즉, 주요의미 맥락에 비해 어휘적 예측이 약한 부가 의미 맥락에서 $\mathrm{N} 400$ 은 관찰되지 않으며, 부적절한 전체 문장의 의 미에 대한 재통합 과정에 대한 P600 성분만 관찰된다고 보았다. 그 러나 본 연구에서는 동음이의어 앞에 부가의미 맥락이 선행하였을 때 N400 성분이 관찰되었으며, 500-800 ms까지 부적 성분이 지속 되었다. 이는 부가의미 맥락 조건에서 주요의미 맥락 조건에서 N400 이 더 강하게 나타난다는 선행연구의 결과와 관련하여 해석할 수 있다(Klepousniotou et al., 2012). 즉, 부가의미 관형어 맥락에서 강 하게 나타난 N400의 부적 성분이 500-800 ms 구간까지도 지속된 다고 해석할 수 있다. 또한 선행연구에 따르면 지속되는 부적 성분 은 맥락에 따라 관련 없는 의미를 억제할 때 관찰된다(Pijnacker et al., 2010). 즉, 선행 맥락에 따라 예측되는 동음이의어 의미가 전체 문장 의미에 부합하지 않는 경우 맥락적으로 관련 없는 의미를 억 제하는 과정에서 지속되는 부적 성분이 관찰된다고 해석할 수도 있다. 이는 동음이의어 처리 시 동음이의어의 주요의미는 맥락에 관계 없이 항상 부분적으로 활성화된다는 선행연구의 결과와 일치 한다(Swaab et al., 2003). 즉, 동음이의어 앞에 주요의미 관형어 맥 락이 선행하였을 때 예측되는 동음이의어의 의미와 전체 문장의
의미가 부합하지 않는다면 동음이의어의 주요의미가 활성화되어 있어 맥락과 관련 없는 동음이의어의 부가의미를 억제하는 대신 전 체 문장 수준에서 의미 통합을 이루려는 재분석이 이루어진다. 반 면, 동음이의어 앞에 부가의미 관형어 맥락이 선행하였을 때 예측 되는 동음이의어의 의미와 전체 문장의 의미가 부합하지 않는다면 맥락과 관련 없이 활성화되어 있는 동음이의어의 주요의미를 억제 하는 과정이 필요하다.

마지막으로, 행동 데이터 분석 결과와 ERP 데이터 분석 결과를 전반적으로 비교해보았다. 오프라인(off-line) 과제인 문장판단과제 의 정반응률과 반응시간에 대해 집단 간 차이가 나타났으며, 관형 어 맥락유형에 따른 집단 간 차이도 나타났다. 특히 정반응률의 경 우, 청년층은 관형어 맥락유형에 따른 동사구 맥락유형 간 차이가 나타나지 않았지만, 노년층은 관형어 맥락유형에 따른 동사구 맥락 유형 간 차이가 나타났다. 그러나 실시간(on-line) 측정방법인 ERP 분석을 통해서는 관형사 맥락유형에 따른 동사구 맥락유형 간 평 균진폭의 차이가 관찰되었으며, 특히 300-500 ms 구간에서 집단 간 평균진폭의 차이가 나타났다. ERP 분석 결과로 얻어진 전체 평 균 파형(grand average waveforms)을 시각적으로 살펴보았을 때, 청년층의 경우 동음이의어 앞에 주요의미 맥락이 선행하였을 때는 300-500 ms 구간에서 N400 성분이 관찰되며, 그 이후 500-800 ms 구간에서는 P600 성분이 관찰된다. 그러나 동음이의어 앞에 부가 의미 맥락이 선행하였을 때는 300-500 ms 구간에서 N400 성분이 관찰되는 것은 동일하지만, $500-800 \mathrm{~ms}$ 구간에서는 P600 성분 대 신 부적성분이 지속된다. 반면, 노년층의 경우에는 모두 부적 성분 이 300-500 ms 구간이 아닌 500-800 ms 구간에서 지연되어 관찰 되었다. 즉, 청년층과 노년층 모두 동음이의어 앞에 선행하는 맥락 에 의해 예측되는 의미와 전체 문장의 의미가 일치하지 않을 때 어 휘적 예측의 어려움으로 부적 성분이 관찰된다는 점은 같으나, 그 이후의 처리 과정에서 차이가 났다.

이는 동음이의어 처리 시 동음이의어의 주요의미는 맥락에 관계 없이 항상 부분적으로 활성화되며, 부가의미는 맥락에 따라 활성 화된다는 재순서 접속(reordered access) 모형을 통해 설명할 수 있 다(Duffy et al., 1988). 정상 청년층은 동음이의어 앞에 주요의미 맥 락이 선행하는 경우 동음이의어의 주요의미만이 활성화되며, 어휘 적 예측이 실패하는 경우 적절한 의미로 문장의 의미를 재통합하 기 위한 재분석 과정이 발생한다. 반면 동음이의어 앞에 부가의미 맥락이 선행하는 경우에는 동음이의어의 주요의미뿐만 아니라 맥 락에 의해 부가의미도 활성화되며, 이에 따라 어휘적 예측이 실패 하는 경우 부적절하게 활성화된 주요의미를 억제하는 과정을 거친 다. 정상 노년층의 경우에는 어휘적 예측에 대한 처리가 지연되어 
나타나며, 그 이후의 처리 과정은 관찰되지 않았다. 특히 부가의미 맥락이 선행하는 경우 중심선 및 우측 영역에서만 지연된 부적 성 분이 관찰되었으며, 전체적으로 현저히 저하된 평균진폭 크기를 보 였다. 이는 동음이의어의 주요의미와 부가의미가 모두 활성화되어 인지적 부담이 커짐으로 인해, 정상 노년층이 특히 부가의미 맥락 에서 동음이의어 처리에 어려움을 겪는 것으로 나타났다. 즉, 노화 에 따라 정상 노년층의 경우에도 뇌 수준에서부터 맥락에 따른 동 음이의어 처리능력에 대해 약화와 지연이 나타나며, 이것이 표면적 으로 발현되는 정반응률 감소나 반응시간 지연의 원인이 될 수 있 음을 시사한다.

본 연구는 행동 및 뇌파 분석을 통해 한국어를 모국어로 하는 청 년층 및 노년층을 대상으로 동음이의어 처리 과정을 살펴본 연구 로서 노화에 따른 동음이의어 처리 과정의 변화를 살펴볼 수 있었 다. 이를 기반으로 차후 정상적인 노화와 치매 등의 질환을 구별하 여 이를 평가하고 중재할 수 있는 프로그램을 개발하는 데 기초자 료를 제공할 수 있다는 점에서 임상적 의의가 있다.

본 연구의 제한점 및 후속 연구를 위한 제언은 다음과 같다. 본 연구에서는 집단을 연령에 따라 만 20-40세는 정상 청년, 만 60-80 세는 정상 노년으로 나누어 연구를 실시하였다. 그러나 청년층의 연령 분포는 20 대, 정상 노년의 연령 분포는 60 대에 집중되어 있으 며, 중장년층을 포함하지 않았다. 동음이의어 처리 과정이 연령에 따라 변화하는 양상을 알아보기 위해 다양한 연령대를 대상으로 한 후속 연구가 진행될 필요가 있다. 또한 본 연구에서는 철자와 소 리가 모두 같은 동철자 동음이의어만을 자극으로 선정하였으나 동 음이의어에는 동철자 동음이의어 외에도 소리는 같지만 철자는 다 른 이철자 동음문자(phonemic writing)이지만 한자의 차이, 종성 자음의 중화 및 한글 맞춤법 규정 등으로 인해 많은 이철자 동음이 의어가 발생한다고 하였다. 따라서 노화에 따른 이철자 동음이의 어 처리 과정이 변화하는지, 동음이의어의 유형에 따른 처리 과정 에 차이가 있는지 알아보기 위한 후속연구가 이루어질 필요가 있 다. 마지막으로, $\mathrm{ERP}$ 분석이 밀리세컨드 단위로 진행되어 시간 해 상도(temporal resolution)에서 강점이 있는 분석 방법이지만, 공간 해상도(spatial resolution)의 정확도가 떨어지는 단점을 가지고 있 다. 따라서, 본 연구에서 뇌영역과 관련된 논의를 자제하였다. 무엇 보다도, 본 연구에서 사용한 분석 방법을 기반으로는 특정 뇌영역 에서 관찰된 뇌파가 반드시 그 뇌파를 발생시킨 근원이 되는지는 알 수 없기 때문이다. 뇌파가 발생한 뇌영역을 밝히기 위해, 향후 source analysis 분석 방법을 적용하여 노화에 따른 언어처리 손상 부위를 밝히는 후속연구가 다양하게 진행될 필요가 있다.

\section{REFERENCES}

Brouwer, H., Fitz, H., \& Hoeks, J. (2012). Getting real about semantic illusions: rethinking the functional role of the $\mathrm{P} 600$ in language comprehension. Brain Research, 1446, 127-143.

Duffy, S. A., Morris, R. K., \& Rayner, K. (1988). Lexical ambiguity and fixation times in reading. Journal of Memory and Language, 27, 429-446.

Dunn, B. R., Dunn, D. A., Languis, M., \& Andrews, D. (1998). The relation of ERP components to complex memory processing. Brain and Cognition, $36,355-376$.

Eum, T. W., \& Kim, E. S. (2004). EEG-based brain computer interface technology. Communications of the Korean Institute of Information Scientists and Engineers, 22, 5-19.

Federmeier, K. D., \& Kutas, M. (2005). Aging in context: age-related changes in context use during language comprehension. Psychophysiology, 42, 133141.

Forster, K. I., \& Bednall, E. S. (1976). Terminating and exhaustive search in lexical access. Memory \& Cognition, 4, 53-61.

Friederici, A. D., Hahne, A., \& Saddy, D. (2002). Distinct neurophysiological patterns reflecting aspects of syntactic complexity and syntactic repair. Journal of Psycholinguistic Research, 31, 45-63.

Glucksberg, S., Kreuz, R. J., \& Rho, S. H. (1986). Context can constrain lexical access: Implications for models of language comprehension. Journal of Experimental Psychology: Learning, Memory, and Cognition, 12, 323-335.

Jasper, H. H. (1958). The ten twenty electrode system of the international federation. Electroencephalography and Clinical Neurophysiology, 10, 371375.

Jeong, H., Yun, H., \& Hong, U. (2015). The representation and processing of polysemy and homonym nouns in Korean sentence comprehension: an ERP study. Language and Linguistics, 68, 149-182.

Kaan, E., Harris, A., Gibson, E., \& Holcomb, P. (2000). The P600 as an index of syntactic integration difficulty. Language and Cognitive Processes, 15, 159-201.

Kang, B. M. (2005). Aspects of the use of homonyms. Language Research, 41, $1-29$.

Kang, Y. (2006). A normative study of the Korean-Mini Mental State Examination (K-MMSE) in the elderly. Korean Journal of Psychology: General, $25,1-12$.

Kang, Y., \& Na, D. L. (2003). Seoul Neuropsychological Screening Battery. Seoul: Human Brain Research \& Consulting Co. 
Kim, B. W. (2009). Improvement of teaching lexical meaning on the Korean education. The International Academic Forum of Korean Language and Literature, 27-44.

Klepousniotou, E., Pike, G. B., Steinhauer, K., \& Gracco, V. (2012). Not all ambiguous words are created equal: an EEG investigation of homonymy and polysemy. Brain and Language, 123, 11-21.

Kutas, M., \& Hillyard, S. A. (1983). Event-related brain potentials to grammatical errors and semantic anomalies. Memory \& Cognition, 11, 539-550.

Kutas, M., \& Hillyard, S. A. (1984). Event-related brain potentials (ERPs) elicited by novel stimuli during sentence processing. Annals of the New York Academy of Sciences, 425, 236-241.

Kwon, Y. A., Cho, H. S., \& Nam, K. C. (2013). The event-related potential evidence of phonological activation in Hangul homophone reading. Journal of Language Sciences, 20, 1-12.

Lee, C. L., \& Federmeier, K. D. (2012). Ambiguity's aftermath: how age differences in resolving lexical ambiguity affect subsequent comprehension. Neuropsychologia, 50, 869-879.

Light, L. L. (1991). Memory and aging: four hypotheses in search of data. Annual Review of Psychology, 42, 333-376.

Lucas, M. M. (1987). Frequency effects on the processing of ambiguous words in sentence contexts. Language and Speech, 30, 25-46.

Luck, S. J. (2014). An introduction to the event-related potential technique. Cambridge, MA: MIT Press.

Na, Y. H. (2014). Behavioral and ERP correlates of Korean homographs in visual word recognition (Master's thesis). Korea University, Seoul, Korea.

National Institute of Korean Language. (2000). The 21st Sejong Project: modern Korean balanced corpus. Seoul: Author.

National Institute of Korean Language. (2005). Frequent use in modern Kore- an research. Seoul: Author.

Olichney, J. M., Taylor, J. R., Gatherwright, J., Salmon, D. P., Bressler, A. J., Kutas, M., \& Iragui-Madoz, V. J. (2008). Patients with MCI and N400 or P600 abnormalities are at very high risk for conversion to dementia. Neurology, 70(19 Part 2), 1763-1770.

Onifer, W., \& Swinney, D. A. (1981). Accessing lexical ambiguities during sentence comprehension: effects of frequency of meaning and contextual bias. Memory \& Cognition, 9, 225-236.

Pijnacker, J., Geurts, B., Van Lambalgen, M., Buitelaar, J., \& Hagoort, P. (2010). Exceptions and anomalies: an ERP study on context sensitivity in autism. Neuropsychologia, 48, 2940-2951.

Simpson, L. L. (1981). The origin, structure, and pharmacological activity of botulinum toxin. Pharmacological Reviews, 33, 155-188.

Smith, M. E. (1993). Neurophysiological manifestations of recollective experience during recognition memory judgments. Journal of Cognitive Neuroscience, 5, 1-13.

Swaab, T., Brown, C., \& Hagoort, P. (2003). Understanding words in sentence contexts: the time course of ambiguity resolution. Brain and Language, 86, 326-343.

Swinney, D. A. (1979). Lexical access during sentence comprehension: (re) consideration of context effects. Journal of Verbal Learning and Verbal Behavior, 18, 645-659.

Taler, V., Klepousniotou, E., \& Phillips, N. A. (2009). Comprehension of lexical ambiguity in healthy aging, mild cognitive impairment, and mild Alzheimer's disease. Neuropsychologia, 47, 1332-1343.

Yoon, M. R. (2015). Age-related differences in ERP components associated with Korean passive sentence processing between young and elderly groups (Master's thesis). Ewha Womans University, Seoul, Korea. 
Appendix 1. 실험문장

\begin{tabular}{|c|c|c|c|c|}
\hline 동음이의어 & 관형어 맥락유형 & 동사구 맥락유형 & 문장 적합성 & 실험문장 \\
\hline \multirow[t]{4}{*}{ 영화 } & 주요 & 주요 & 적합 & 여자가 무서운 영화를 즐겨 보다 \\
\hline & & 부가 & 부적합 & 여자가 무서운 영화를 한순간에 잃다 \\
\hline & 부가 & 부가 & 적합 & 남자가 찬란한 영화를 한순간에 잃다 \\
\hline & & 주요 & 부적합 & 남자가 찬란한 영화를 즐겨 보다 \\
\hline \multirow[t]{4}{*}{ 시장 } & 주요 & 주요 & 적합 & 여자가 오래된 시장을 자주 가다 \\
\hline & & 부가 & 부적합 & 여자가 오래된 시장을 신중히 뽑다 \\
\hline & 부가 & 부가 & 적합 & 남자가 유능한 시장을 신중히 뽑다 \\
\hline & & 주요 & 부적합 & 남자가 유능한 시장을 자주 가다 \\
\hline \multirow[t]{4}{*}{ 의식 } & 주요 & 주요 & 적합 & 여자가 또렷한 의식을 순간적으로 잃다 \\
\hline & & 부가 & 부적합 & 여자가 또렷한 의식을 성공적으로 치르다 \\
\hline & 부가 & 부가 & 적합 & 남자가 성대한 의식을 성공적으로 치르다 \\
\hline & & 주요 & 부적합 & 남자가 성대한 의식을 순간적으로 잃다 \\
\hline \multirow[t]{4}{*}{ 지방 } & 주요 & 주요 & 적합 & 여자가 여러 지방을 차례로 방문하다 \\
\hline & & 부가 & 부적합 & 여자가 여러 지방을 쏙 빼다 \\
\hline & 부가 & 부가 & 적합 & 남자가 두꺼운 지방을 쏙 빼다 \\
\hline & & 주요 & 부적합 & 남자가 두꺼운 지방을 차례로 방문하다 \\
\hline \multirow[t]{4}{*}{ 고개 } & 주요 & 주요 & 적합 & 여자가 뻐근한 고개를 천천히 끄덕이다 \\
\hline & & 부가 & 부적합 & 여자가 뻐근한 고개를 간신히 넘다 \\
\hline & 부가 & 부가 & 적합 & 남자가 가파른 고개를 간신히 넘다 \\
\hline & & 주요 & 부적합 & 남자가 가파른 고개를 천천히 끄덕이다 \\
\hline \multirow[t]{4}{*}{ 은행 } & 주요 & 주요 & 적합 & 여자가 가까운 은행을 급히 들르다 \\
\hline & & 부가 & 부적합 & 여자가 가까운 은행을 가득 줍다 \\
\hline & 부가 & 부가 & 적합 & 남자가 맛있는 은행을 가득 줍다 \\
\hline & & 주요 & 부적합 & 남자가 맛있는 은행을 급히 들르다 \\
\hline \multirow[t]{4}{*}{ 입장 } & 주요 & 주요 & 적합 & 여자가 반대의 입장을 강하게 주장하다 \\
\hline & & 부가 & 부적합 & 여자가 반대의 입장을 질서정연하게 기다리다 \\
\hline & 부가 & 부가 & 적합 & 남자가 미뤄진 입장을 질서정연하게 기다리다 \\
\hline & & 주요 & 부적합 & 남자가 미뤄진 입장을 강하게 주장하다 \\
\hline \multirow[t]{4}{*}{ 관리 } & 주요 & 주요 & 적합 & 여자가 비싼 관리를 꾸준히 받다 \\
\hline & & 부가 & 부적합 & 여자가 비싼 관리를 매우 칭찬하다 \\
\hline & 부가 & 부가 & 적합 & 남자가 청렴한 관리를 매우 칭찬하다 \\
\hline & & 주요 & 부적합 & 남자가 청렴한 관리를 꾸준히 받다 \\
\hline \multirow[t]{4}{*}{ 의사 } & 주요 & 주요 & 적합 & 여자가 젊은 의사를 살며시 부르다 \\
\hline & & 부가 & 부적합 & 여자가 젊은 의사를 은근히 내비치다 \\
\hline & 부가 & 부가 & 적합 & 남자가 거절의 의사를 은근히 내비치다 \\
\hline & & 주요 & 부적합 & 남자가 거절의 의사를 살며시 부르다 \\
\hline \multirow[t]{4}{*}{ 거리 } & 주요 & 주요 & 적합 & 여자가 붐비는 거리를 한참 헤매다 \\
\hline & & 부가 & 부적합 & 여자가 붐비는 거리를 점점 좁히다 \\
\hline & 부가 & 부가 & 적합 & 남자가 서먹한 거리를 점점 좁히다 \\
\hline & & 주요 & 부적합 & 남자가 서먹한 거리를 한참 헤매다 \\
\hline \multirow[t]{4}{*}{ 바람 } & 주요 & 주요 & 적합 & 여자가 찬 바람을 늦게까지 쐬다 \\
\hline & & 부가 & 부적합 & 여자가 찬 바람을 마침내 이루다 \\
\hline & 부가 & 부가 & 적합 & 남자가 간절한 바람을 마침내 이루다 \\
\hline & & 주요 & 부적합 & 남자가 간절한 바람을 늦게까지 쐬다 \\
\hline \multirow[t]{4}{*}{ 사고 } & 주요 & 주요 & 적합 & 여자가 갑작스러운 사고를 심하게 당하다 \\
\hline & & 부가 & 부적합 & 여자가 갑작스러운 사고를 잘못 가지다 \\
\hline & 부가 & 부가 & 적합 & 남자가 편협한 사고를 잘못 가지다 \\
\hline & & 주요 & 부적합 & 남자가 편협한 사고를 심하게 당하다 \\
\hline \multirow[t]{4}{*}{ 가정 } & 주요 & 주요 & 적합 & 여자가 단란한 가정을 마침내 꾸리다 \\
\hline & & 부가 & 부적합 & 여자가 단란한 가정을 많이 세우다 \\
\hline & 부가 & 부가 & 적합 & 남자가 흥미로운 가정을 많이 세우다 \\
\hline & & 주요 & 부적합 & 남자가 흥미로운 가정을 마침내 꾸리다 \\
\hline
\end{tabular}


Appendix 1. (계속)

\begin{tabular}{|c|c|c|c|c|}
\hline 동음이의어 & 관형어 맥락유형 & 동사구 맥락유형 & 문장 적합성 & 실험문장 \\
\hline \multirow[t]{4}{*}{ 다리 } & 주요 & 주요 & 적합 & 여자가 다친 다리를 몹시 절다 \\
\hline & & 부가 & 부적합 & 여자가 다친 다리를 간신히 건너다 \\
\hline & 부가 & 부가 & 적합 & 남자가 좁은 다리를 간신히 건너다 \\
\hline & & 주요 & 부적합 & 남자가 좁은 다리를 몹시 절다 \\
\hline \multirow[t]{4}{*}{ 감정 } & 주요 & 주요 & 적합 & 여자가 언짢은 감정을 고스란히 드러내다 \\
\hline & & 부가 & 부적합 & 여자가 언짢은 감정을 여러 차례 요청하다 \\
\hline & 부가 & 부가 & 적합 & 남자가 전문적인 감정을 여러 차례 요청하다 \\
\hline & & 주요 & 부적합 & 남자가 전문적인 감정을 고스란히 드러내다 \\
\hline \multirow[t]{4}{*}{ 시각 } & 주요 & 주요 & 적합 & 여자가 부정적인 시각을 무심코 드러내다 \\
\hline & & 부가 & 부적합 & 여자가 부정적인 시각을 한참 넘기다 \\
\hline & 부가 & 부가 & 적합 & 남자가 약속한 시각을 한참 넘기다 \\
\hline & & 주요 & 부적합 & 남자가 약속한 시각을 무심코 드러내다 \\
\hline \multirow[t]{4}{*}{ 기사 } & 주요 & 주요 & 적합 & 여자가 자세한 기사를 꼼꼼히 읽다 \\
\hline & & 부가 & 부적합 & 여자가 자세한 기사를 신중히 고용하다 \\
\hline & 부가 & 부가 & 적합 & 남자가 실력있는 기사를 신중히 고용하다 \\
\hline & & 주요 & 부적합 & 남자가 실력있는 기사를 꼼꼼히 읽다 \\
\hline \multirow[t]{4}{*}{ 지도 } & 주요 & 주요 & 적합 & 여자가 펼쳐진 지도를 잘못 보다 \\
\hline & & 부가 & 부적합 & 여자가 펼쳐진 지도를 매주 받다 \\
\hline & 부가 & 부가 & 적합 & 남자가 엄격한 지도를 매주 받다 \\
\hline & & 주요 & 부적합 & 남자가 엄격한 지도를 잘못 보다 \\
\hline \multirow[t]{4}{*}{ 임금 } & 주요 & 주요 & 적합 & 여자가 적은 임금을 대폭 인상하다 \\
\hline & & 부가 & 부적합 & 여자가 적은 임금을 진심으로 섬기다 \\
\hline & 부가 & 부가 & 적합 & 남자가 어진 임금을 진심으로 섬기다 \\
\hline & & 주요 & 부적합 & 남자가 어진 임금을 대폭 인상하다 \\
\hline \multirow[t]{4}{*}{ 용기 } & 주요 & 주요 & 적합 & 여자가 고백할 용기를 선뜻 내다 \\
\hline & & 부가 & 부적합 & 여자가 고백할 용기를 실수로 깨뜨리다 \\
\hline & 부가 & 부가 & 적합 & 남자가 네모난 용기를 실수로 깨뜨리다 \\
\hline & & 주요 & 부적합 & 남자가 네모난 용기를 선뜻 내다 \\
\hline
\end{tabular}




\section{국문초록}

\section{관형어 및 동사구 맥락유형에 따라 동음이의어 처리 과정에서 나타나는 청년층 및 노년층 간 ERP 성분 비교 조은하 · 성지은 \\ 이화여자대학교 대학원 언어병리학과}

배경 및 목적: 본 연구는 청년층과 노년층을 대상으로 ERP 실험을 진행하여 동음이의어 처리 시 맥락유형에 따른 차이가 있는지 살펴 보았다. 방법: 청년층 22 명과 노년층 20 명을 대상으로 문장판단과제를 실시하여 정반응률과 반응시간을 측정하는 동시에 뇌전도를 녹 화하였다. 동음이의어 전후에 관형어 및 동사구 맥락이 포함된 문장을 사용하였으며, 각 맥락유형은 의미 편향성에 따라 주요의미 맥 락'과 ‘부가의미 맥락’으로 나누었다. 결과: 정반응률과 반응시간에서 청년층에 비해 노년층의 정반응률이 더 낮고, 반응시간도 더 느렸 다. ERP 데이터 분석 결과, 300-500 ms 구간에서 노년층의 경우, 청년층에 비해 유의하게 진폭이 감소한 것으로 나타났다. 청년층의 경 우주요의미 관형어 맥락유형에서 동사구 맥락유형이 이와 일치하지 않을 때 N400과 P600 성분이 관찰되었으며, 부가의미 관형어 맥락 유형에서 동사구 맥락유형이 이와 일치하지 않을 때는 N400과 지속된 부적 성분(sustained negativity)이 관찰되었다. 반면, 노년층의 경우 관형어 맥락유형과 상관없이 500-800 ms 구간에서 지연된 부적 성분이 관찰되었다. 논의 및 결론: 청년층에서 주요의미 관형어 맥락유형에서 관찰된 N400과 $\mathrm{P} 600$ 은 각각 선행 맥락에 의해 활성화된 동음이의어의 의미가 전체 문장의 의미에 부합하지 않은 경우 발생하는 어휘적 예측의 실패와 이후 의미 통합의 실패로 인한 재분석 과정을 반영하는 것으로 해석된다. 또한 부가의미 관형어 맥락에 서 관찰된 N400이 어휘적 예측의 실패를 반영하는 점은 동일하나 이후 관찰된 지속된 부적 성분은 선행 맥락에 관계없이 활성화되어 있는 동음이의어의 주요의미를 억제하는 과정을 반영하는 것으로 보인다. 그러나 노년층에서 관찰된 지연된 부적 성분은 노화에 따라 동음이의어 처리에 대해 약화와 처리속도 저하에 의해 나타난 것으로 해석된다.

핵심어: 노년층, 동음이의어, 맥락, 사건관련전위, $\mathrm{N} 400, \mathrm{P} 600$

본 논문은 2016년 대한민국 교육부와 한국연구재단의 지원을 받아 수행된 연구임(No. NRF-2017R1A2B4006604).

\section{참고문헌}

강범모(2005). 동음이의어의 사용 양상. 어학연구, 41, 1-29.

강연욱(2006). K-MMSE (Korean-Mini Mental State Examination)의 노인 규준 연구. 한국심리학회지: 일반, 25, 1-12.

강연욱, 나덕렬(2003). 서울신경심리검사(Seoul Neuropsychological Screening Battery). 서울: 휴브알엔씨.

국립국어원(2000). 21세기 세종계획: 국어 기초자료 - 연구 교육용 1,000만 어절 현대국어 균형 말뭉치. 서울: 국립국어원.

국립국어원(2005). 현대국어사용빈도조사. 서울: 국립국어원.

권유안, 조혜숙, 남기춘(2013). 글 단어 읽기 이해에서 음운 정보의 활성화: 동음이의어의 사건관련뇌파 증거. 언어과학, 20, 1-12.

김병운(2009). 한국어교육에서 어휘 의미 교육의 개선방향 한국어문학 국제학술포럼 학술대회, 27-44.

윤미류(2015). 한국어 피동형 문장처리 과정에서 나타나는 청년층 및 노년층간 ERP 성분 차이 분석. 이화여자대학교 대학원 석사학위논문.

음태완, 김응수(2004). 뇌파기반 뇌-컴퓨터 인터페이스 기술. 정보과학회지, 22, 5-19.

정혜인, 윤홍옥, 홍우평(2015). 한국어 문장이해에서 다의어와 동음이의어의 표상과 처리: ERP 연구. 언어와 언어학, 68, 149-182. 